DOI: 10.32089/WBH.PHW.2021.2(276).0001

orcid.org/0000-0002-8144-2120

\author{
TOMASZ KARPIŃSKI
}

(Poznań)

\title{
Umundurowanie Chorągwi Piechoty Węgierskiej Buławy Polnej Koronnej w latach 1752-1768
}

\begin{abstract}
The uniform of the Hungarian Crown Field Mace Infantry Banner in the years 1752-1768 has not been the subject of research so far. The author of this text presents the evolution of the uniform, equipment and partly armaments of the unit on a rich source basis from the resources of the National Archives in Krakow. The banner had a red-sapphire uniform with traditional Hungarian accents (e.g. long trousers, a zupanik instead of a vest, a Hungarian yarn belt, a saber tie, etc.), also observed in the Austrian army in Hungarian regiments.

Umundurowanie Chorągwi Piechoty Węgierskiej Buławy Polnej Koronnej w okresie saskim nie było jak do tej pory przedmiotem zainteresowania historyków. Nie wspomina o nim ani Konstanty Górski w swojej historii piechoty ${ }^{1}$, ani nie zostało ono opisane przez Bronisława Gembarzewskiego. ${ }^{2}$ Tomasz Ciesielski w swoim monumentalnym dziele o armii koronnej w czasach

\footnotetext{
1 Konstanty Górski, Historya piechoty polskiej (Kraków: Księgarnia Spółki Wydawniczej Polskiej, 1893). Górski wspomina o istnieniu chorągwi na kilku stronach, m.in. 93, 116, 121, 135, jednak nie poświęca im nawet choćby kilku zdań.

2 Bronisław Gembarzewski, Żolnierz polski. Ubiór, uzbrojenie i oporządzenie od wieku XI do roku 1960, t. 2, Od 1697 do 1794 roku (Warszawa: Wyd. Ministerstwa Obrony Narodowej, 1962), na tablicy 65, fig. D i E ukazano najprawdopodobniej „Węgrów” chorągwi marszalkowskiej, a na tablicy 147 skopiowana została grafika z pozycji: Gabriel N. Raspe, Accurate Vorstellung der Königlich Pohlnischen Armee nach der auf dem in Jahre 1775 gehaltenen Reichstage festgesetzten Stärke und Uniform (Nürnberg: Raspe, Gabriel Nikolaus, 1781), tab. nr 47 i 48, b.n.s.
} 
Augusta III poświęcił charakterystyce umundurowania chorągwi węgierskich dwa akapity. W pierwszym przedstawione zostało umundurowanie chorągwi należącej do hetmana wielkiego Jana Klemensa Branickiego. ${ }^{3}$ Porównując zebrany materiał źródłowy z przedstawionym tam opisem, musimy dojść do wniosku, iż jest on nieadekwatny lub co najmniej niereprezentatywny w przypadku opisu umundurowania żołnierzy dla obu chorągwi piechoty węgierskiej. W oddziale hetmana Branickiego noszono m.in. skórzane pludry, zakolanniki czy „podkoszulki” (może półkoszule?). ${ }^{4} \mathrm{~W}$ chorągwi Rzewuskiego spodnie były sukienne, a dwie ostatnie formy mundurowe $\mathrm{w}$ ogóle nie występowały. W drugim akapicie dotyczącym umundurowania chorągwi piechoty węgierskiej Ciesielski wskazał jedynie barwy poszczególnych oddziałów. ${ }^{5} \mathrm{~W}$ związku z tym autor niniejszego tekstu uznał, że należy przedstawić szczegółowo elementy umundurowania „Węgrów” chorągwi buławy polnej i uzupełnić tym samym stan wiedzy dotyczącej tego zagadnienia.

Po śmierci hetmana wielkiego koronnego Józefa Potockiego w 1751 r. dowodzenie nad jego oddziałem przejął dotychczasowy hetman polny Jan Klemens Branicki, który podniósł do rangi Chorągwi Buławy Wielkiej swój dotychczasowy oddział przyboczny, natomiast Chorągiew Piechoty Węgierskiej Potockiego zdegradowana została do roli chorągwi przybocznej hetmana polnego koronnego. ${ }^{6}$ Ordynansem z 7 czerwca 1752 r. Branicki przekazał formalne dowodzenie nad chorągwią Wacławowi Rzewuskiemu. Wydarzenia te zbiegły się także ze zmianą rotmistrza w oddziale. W chwili przejęcia dowodzenia nad chorągwią przez nowego hetmana polnego jej dowódcą, po rezygnacji dotychczasowego pułkownika L. Małachowskiego ${ }^{7}$, był od lutego $1752 \mathrm{r}$. rotmistrz Franciszek Bałła ${ }^{8}$, błędnie identyfikowany z Bottą ${ }^{9}$, Battą ${ }^{10}$ lub Bułłą ${ }^{11}$.

\footnotetext{
3 Tomasz Ciesielski, Armia koronna w czasach Augusta III (Warszawa: Wyd. DiG, 2009), 477.

4 Ibid.

5 Ibid., 479.

6 Ibid., 338-339.

7 Nie udało się ustalić pełnego imienia Małachowskiego.

8 Taka leksja nazwiska wynika m.in. z całego szeregu dokumentów cytowanych w niniejszym tekście, a także w innych opracowaniach. Bratem Franciszka był Aleksander, służący w tym samym czasie jako kapitan w Regimencie Konnym Buławy Polnej Koronnej, zob. Mariusz Machynia i Czesław Srzednicki, Oficerowie wojska Koronnego 1777-1794: spisy, cz. 1, Sztaby i kawaleria (Kraków: Księgarnia Akademicka, 2002), 429.
}

$9 \quad$ Podhorce: dzieje wnętrz pałacowych i galerii obrazów, oprac. Jan K. Ostrowski et al. (Kraków: Zamek Królewski na Wawelu, 2001), 72.

10 Zob. Ciesielski, Armia, 141 oraz 338, przyp. 85.

11 Gembarzewski, Rodowody pułków i oddziałów równorzędnych od r. 1717 do r. 1831 (Warszawa: Towarzystwo Wiedzy Wojskowej, 1925), 23; zob. także aneks nr 1. 
Pozostawał on na czele chorągwi aż do swojej śmierci 7 września 1768 r. Komendę po nim objął $\mathrm{z}$ kolei porucznik Jan Sidorowski. ${ }^{12}$

Ramy chronologiczne pracy zbiegają się z okresem dowodzenia chorągwią przez Franicszka Bałłę, a także z zachowanym materiałem źródłowym. Najwcześniejszy bowiem z zachowanych dokumentów - z lipca 1752 r. dotyczy lustracji potrzeb i zakupów, jakie należy poczynić, aby „uzupełnic”" i „dokompletować" umundurowanie dla oddziału. ${ }^{13}$ Daje on zresztą pogląd na wygląd munduru „Węgrów” z okresu wcześniejszego, gdy chorągiew służyła Józefowi Potockiemu. Z kolei ostatni z dokumentów pochodzi z 22 listopada 1768 r. i przedstawia skrócony wyciąg z wydatków poczynionych na uzbrojenie i umundurowanie chorągwi. ${ }^{14} \mathrm{~W}$ przypadku opisywanego oddziału możemy mówić o wyjątkowej sytuacji, gdyż posiadamy dla niego niemal pełny materiał archiwalny. Dla okresu od 1752 r. do 1768 r. z wyjątkiem 1762 r., który przedstawia ograniczoną do tkanin listę potrzeb - mamy pełny wykaz specyfikacji elementów umundurowania i uzbrojenia zakupywanego w ramach tzw. wielkiego munduru, który to termin zostanie wyjaśniony poniżej. Informacje te uzupełniają m.in. listy zakupów elementów tzw. małego munduru $(1756,1761,1763,1767)$ oraz wykazy strat w ekwipunku i barwie spowodowanych przez dezercje.

Barwą chorągwi za czasów Potockiego były kolory: czerwony noszony na katankach oraz granatowy na „kamizelkach”. ${ }^{15}$ Najprawdopodobniej pod koniec życia hetmana kolor granatowy zastąpiony został przez szafirowy, występujący także w pozostałych podległych mu oddziałach: regimencie pieszym i regimencie konnym. Nowy szef oddziałów hetmańskich - Wacław Rzewuski - pozostał przy tej barwie zmieniając jednak niektóre elementy umundurowania.

Chorągiew Piechoty Węgierskiej Buławy Polnej Koronnej tworzyło: 3 oficerów (rotmistrz, porucznik i chorąży), wachmistrz (sierżant), podchorąży, 3 kaprali, felczer, 4 muzyków kompanijnych (do października 1754 r.

12 Archiwum Narodowe w Krakowie (dalej: AN w Krakowie), Archiwum Sanguszków, Archiwum podhoreckie (dalej: AS, Ap), Podh IV/XLVII, plik 86, Regestr dokumentów do likwidacji chorągwi pieszey węgierskiej pana Sidorowskiego rotmistrza potrzebnych a d[ie] 1 Marty 1768 Anni, aż ad Mensem Aprlis 1769, Podhorce, 28 I 1774 r., b.p.

13 Ibid., plik 23, Specyfikacya munderunku chorągwi węgierskiey buławy polney koronney in Anno p. Tenti 1752 należącego wyrażeniem 1 mo co na niego in specie różnych rzeczy wychodzi; 2do co się z tych rzeczy u jmco pana Rothmistrza już gotowych znayduie; 3tio co się zaś do kupienia y na co JWJmci pan hetman daię pieniądze, Chełm, 17 VII 1752 r., b.p.

14 Ibid., plik 85, Expens na mundur wielki należący piechocie węgierskiey buławy polney koronney in anno 1768 y wszelkie rekwizyta do tegoż munduru tudzież ledewerk reparacyą broni y inne wydatki, b.m., 22 XI 1768 r., b.p.

15 Ibid., Podh II 74, Moderunek authoramentu cudzoziemskiego, jak się teraz noszą w woysku koronnym, b.m., [ca. 1751 r.], b.p. 
1 fajfer ${ }^{16}$ i 2 doboszy, od listopada tr. 2 fajfrów i doboszy) i 60 gemeinów. ${ }^{17}$ $\mathrm{Na}$ zachowanych listach płac z tego okresu brak woźnicy. ${ }^{18}$ Oddział nie posiadał także furiera ${ }^{19}$, a na egzakcje, czyli pobór podatku na utrzymanie oddziału, wysyłani byli oficerowie, m.in. Franciszek Bałła (luty 1752 r.), Michał Erdelli (luty, wrzesień 1753 r.), Tomasz Watlewski (październik 1761 r.), Jan Sidorowski (marzec, wrzesień 1766 r.; marzec, sierpień 1767 r.; wrzesień 1768 r.). ${ }^{20}$

Oddział stanowił eskortę przyboczną hetmana i towarzyszył mu w większości reprezentacyjnych podróży lub jako asysta wojskowa. W grudniu 1752 r. chorągiew znajdowała się w Chełmie, 15 maja 1754 r. rotmistrz Bałła otrzymał rozkaz do wymarszu z oddziałem do Warszawy, a 29 czerwca 1754 r. pod Drohiczyn na wojskowe koło generalne. Następnie oddział krążył między Warszawą (lipiec 1754 r.) a Chełmem (sierpień-październik 1754 r.), by w listopadzie powrócić do Warszawy. Lenunglisty, czyli listy wydanego żołdu (lenung/traktament) z lutego 1755 i 1756 r. wskazują na pobyt chorągwi w Dubnie. W okresie 9 sierpnia 1756 r. - 24 stycznia 1757 r. oddział pokonywał drogę do Chełma, następnie z Chełma do Warszawy, a ze stolicy na powrót do Podhorzec. Ponownie w 1758 r. oddział przebywał w Warszawie (październik-listopad), znajdował się poza Podhorcami w okresie 11 września 1758 r. - 18 grudnia 1758 r. Marsze do i z Warszawy chorągiew odbywała także: 12 września 1760 r. - 4 listopada 1760 r., 1 kwietnia 1761 r. - 2 czerwca 1761 r., 15 kwietnia 1763 r. - 27 kwietnia 1763 r., 15 kwietnia 1764 r. - 30 maja 1764 r. oraz w listopadzie 1767 r. Widzimy zatem, iż w przeciwieństwie do leibkompanii Regimentu Pieszego Buławy Polnej Koronnej stacjonującego również w Podhorcach „Węgrzy” byli chętnie przemieszczani $\mathrm{z}$ miejsca na miejsce. ${ }^{21} \mathrm{O}$ ich szczególnej roli jako oddziału przybocznego świadczy choćby rozkaz udania się do Lwowa

16 Fajfer był muzykiem grającym na piszczałkach, miał zazwyczaj dwa instrumenty o różnych długościach, które trzymał w specjalnym futerale.

17 Słowo gemein lub gemajn pochodzi od spolszczonego słowa Gemeyne, którym to w j. niemieckim określano szeregowych żołnierzy.

18 Zob. aneks nr 1.

19 Podoficer odpowiedzialny m.in. za przydział kwater, prowadzenie dokumentacji rachunkowej oraz kompanijnej, rozdział żywności w czasie przemarszów itp.; więcej o powinnościach furiera zob.: AN w Krakowie, AS, Ap, Podh II 8, Powinności żołnierskie, b.m., [po 1742 r.], 49-51.

20 Ibid., Podh II 111, Kopie ordynansów (Podhorce) z następujących dni: 14 II 1752 r., 22; 12 II 1753 r., 27-28; 12 IX 1753 r., 32; 23 X 1761 r., 206-207; 6 III 1766 r., 304; 1 IX 1766 r., 308; marzec 1767 r., 322; 22 VIII 1767 r., 324, 10 IX 1768 r., 327.

${ }^{21}$ Leibkompania $\mathrm{w}$ okresie stacjonowania w Podhorcach opuściła miejsce pobytu tylko raz w lipcu 1758 r., podczas marszu na koło rycerskie, „które było na Błoni pod Lwowem"; zob. ibid., Podh III, pudło V/1, plik 22, Ordynans Wacława Rzewuskiego do Samuela 
w 1763 r. w celu zaciągnięcia warty przed kamienicą na czas pobytu hetmana w mieście i jego uroczystego przywitania, który to pobyt wraz z podróżą zajął chorągwi dokładnie 12 dni. Poza wymarszami żołnierze chorągwi pełnili normalną służbę garnizonową w Podhorcach wespół ze wspomnianą leibkompanią. Jedynie w okresie 16 maja 1758 r. - 25 czerwca 1758 r. służba ta odbywała się naprzemiennie: raz wartę pełniła tylko „Infanteria”, a następną tylko „Węgrzy”.22

Umundurowanie żołnierzy chorągwi, podobnie jak w przypadku piechoty autoramentu cudzoziemskiego, składało się z tzw. „wielkiego” i „małego munduru”. Dokładne określenie wszystkich elementów jest niezwykle trudne, gdyż często elementy małego munduru były zakupywane wraz z częściami wielkiego, czyniąc rozróżnienie ich bardzo trudnym. Możemy pokusić się jednak o przedstawienie zbliżonego zestawienia. W skład wielkiego munduru wchodziły m.in. katanka (suknia) wierzchnia i spodnia (żupanik), nakrycie głowy, sukienne obszycie tarszuli i halsztuk. W skład małego munduru wchodziła bielizna, tj. koszule, spodnie wraz z dodatkami, buty oraz kitle. Wielki mundur wydawany był tak jak w piechocie autoramentu cudzoziemskiego w okresie dwuletnim, natomiast mały co roku. ${ }^{23}$

Brodowskiego, Podhorce, 24 VII 1758 r., b.p.; Podh II 67, Żornal ad leybkompaniej regimentu pieszego buławy polnej koronnej w Podhorcach, Podhorce, 25 VII 1758 r., 56.

22 Ibid., Podh II 67, Żornal..., 10 IX 1760 r., 130; 1 IV 1761 r., 148; 28 I 1763 r., 190; 15 IV 1763 r., 196; Podh II 111, Kopie ordynansów (Podhorce) z dni: 15 V 1754 r., 70; 27 VI 1754 r., 83; 12 IX 1755 r., 110-111; 7 VIII 1756 r., 131; 20 XII 1756 r., 136; 10 IX 1760 r., 177; 28 X 1760 r., 178; 26 III 1761 r., 181; 29 V 1761 r., 183; 28 I 1763 r., 233-234; 11 IV 1764 r., 253; Podh III, pudło IV/1, pliki 1-205f, Rolle lenungowe, 1752-1769, b.p.; Podh II 253, Raporty dzienne stanu warty regimentu pieszego buławy polnej koronnej na zamku w Podhorcach, Podhorce, 29 XII 1755 r. - 25 VI 1758 r., b.p.; Podh II 268, Księga raportów hauptwachu, Podhorce, 25 VII 1758 r. - 7 XII 1758 r.; Podh II 106, Księga raportów leybkompanii stacjonowanej w zamku podhoreckim, Podhorce, 27 IX 1758 r. - 9 III 1760 r., b.p.; Podh II 28, Księga raportów regimentu pieszego buławy polnej koronnej stacjonowanego w Podhorcach, Podhorce, 29 VIII 1762 r. - 25 IV 1763 r., b.p.

23 Ibid., Podh IV/XLVII, plik 11, Regestr percepty y expensy na drobny moderunek dla chorągwi piechoty węgierskiey jaśnie wielmożnego jmci pana hetmana polnego koronnego wodza y dobrodzieja należącey pro 1ma Augusti 1753 r. co iest na rok cały ad 1mam augusti 1754, Podhorce, 8 IX 1753 r., b.p.; plik 13, Specyfikacja rekwizytów dla chorągwi piechoty węgierskiey jaśnie wielmożnego jmci pana woiewody podolskiego hetmana polnego koronnego dobrodzieia pro die 1ma Augusti w tymże roku do barwy należących, Podhorce, 29 III 1754 r., b.p. [także Podh II 230, 18-21]; plik 17, Rejestr percept y expens dla ludzi chorągwi piechoty węgierskiey jaśnie wielmożnego jmci pana woiewody podolskiego hetmana polnego koronnego ten sprawunek należący do mondoru wielkiego dwuletniego pro 1ma Augusti 1754 anni która percepta y expensa niżey się specyfikuje, b.m., 11 IV 1754 r., b.p.; plik 25, Specyfykacya małego moderunku dla ludzi chorągwi piechoty węgierskiey jaśnie wielmożnego jmci pana woiewody podolskiego hetmana polnego koronnego należoney pro prima Augusti 1761 na rok cały, aż do monduru wielkiego in anno 1762 przypadaiącego, Podhorce, 13 VII 1761 r., b.p.; plik 59, Regestr percepty y expensy dla ludzi chorągwi piechoty węgierskiej komputowey jaśnie wielmożnego 
Nakrycie głowy wszystkich żołnierzy chorągwi stanowiła kapuza. Na podstawie opisów materiałów przeznaczanych do jej wykonania możemy uznać, iż był to rodzaj kołpaka lub sukiennej czapki z ruchomym wyłogiem. Wykonywano ją z 0,5 łokcia $^{24}$ sukna czerwonego na dzwon i $3 / 8$ łokcia sukna szafirowego na obłóg/wyłóg. Gatunek używanego sukna zależał od szarży żołnierza. Dla szeregowych używano sukna ordynaryjnego zwanego także trzydziestowym od franc. trentain, co pierwotnie oznaczało tkaninę wykonaną z 30 grup nici po 100 nici w osnowie lub dające 3 tys. nici $\mathrm{w}$ osnowie. Tkaniny takie produkowane początkowo $\mathrm{w}$ Langwedocji i Prowansji cechowały się wysoką jakością. ${ }^{25}$ W XVIII w. była to już nazwa zwyczajowa i oznaczała sukno o niskiej jakości wynoszącej około 7-10 nitek osnowy na $1 \mathrm{~cm} .{ }^{26}$ Elementy munduru podoficerów wykonywano z lepszego sukna czterdziestowego (im cieńsze nitki w osnowie, tym więcej nitek na $\mathrm{cm}$, a także delikatniejsze i lepsze jakościowo sukno). ${ }^{27} \mathrm{Na}$ podszewkę przeznaczano także około dwóch ćwierci (pół arszyna ${ }^{28}$ ) płótna konopnego. ${ }^{29} \mathrm{~W}$ latach pięćdziesiątych XVIII w. zdobiono je ponadto białą taśmą

pana wojewody krakowskiego hetmnana koronnego a to na mondur wielki dwuletni należący a die prima 1766 a[nn]o, która percepta y expensa niżey się specyfikuie, [Podhorce], 13 XII 1766 r., b.p.; plik 71, Specyfikacya potrzeb należących [ludzi chorągwi piechoty węgierskiej] wojewody krakowskiego hetman[a polnego koronnego pro] prima augusti 1767 na rok cały aż do [1768], Podhorce, 1768 r., b.p.; Podh IV/XL, plik 1, Specyfikacja drobnego moderunku dla ludzi chorągwi piechoty węgierskiey buławy polney koronney pro 1ma Augusti 1755 w należącey na rok cały to iest ad 1mam Augusti 1756 anni aż do wielkiego munduru podana, Podhorce, 29 VII 1755 r., b.p.; plik 20, Specyfikacya potrzeb do monduru wielkiego należącego pro $1 \mathrm{ma}$ Augusti 1758 która potrzeba, aby wcześni wygotowane skupione dla chorągwi piechoty węgierskiey jw. pana wojewody podolskiego hetmana polnego koronnego które potrzeby różne niżey się opisuią, Podhorce, 24 IV 1758 r., b.p.

24 Podstawową jednostką miary w owym czasie był łokieć, który w zależności od regionu miał inną długość.

25 Johann Christian Schedel, Neues und vollständiges, allgemeines Waaren-Lexikon, t. 2 (Offenbach am Mayn: Carl Ludwig Brede, 1814), 506; Johann Friedrich Heigelin, Allgemeines Fremdwörter-Handbuch für Teutsche (Tübingen: Verlag von E. F. Osiander, 1838), 1157.

26 Więcej informacji o rodzajach materiałów i tkanin używanych w XVIII w. do produkcji mundurów znajdzie czytelnik w opracowaniu Tomasz Karpiński, „Rola Leszna w zaopatrzeniu piechoty koronnej w umundurowanie i ekwipunek za czasów Augusta III - wybór źródeł," Rocznik Leszczyński 19, (2019): 229-236.

27 AN w Krakowie, AS, Ap, Podh IV/XLVII, plik 23, Specyfikacya munderunku chorągwi..., 17 VII 1752 r., b.p.

28 Jednostka miary oznaczająca 6/4 (arszyn dużej miary) lub 5/4 (arszyn małej miary) łokcia, czyli między $89,28 \mathrm{~cm}$ a 70,8 cm w zależności od wielkości arszyna i łokcia, zob. Karpiński, „Rola,” 247.

29 AN w Krakowie, AS, Ap, Podh IV/XLVII, plik 17, Rejestr percept y expens..., 11 IV 1754 r., b.p.; plik 25, Specyfykacya małego moderunku..., 13 VII 1761 r., b.p.; Podh IV/XL, plik 20, Specyfikacya potrzeb do monduru wielkiego..., 24 IV 1758 r., b.p.; Podh IV/L, plik 
włóczkową na obłogach (po 3 łokcie na kapuzę), takimż kutasikiem wełnianym i guzikiem mocującym chwosta (ozdobne zakończenie sznura). $\mathrm{Na}$ przedzie umieszczano „cyfrę" wykonywaną z wąskiej taśmy włóczkowej (po 2,5 łokcia na cyfrę). W 1761 r. taśma taka kosztowała 8 gr za łokieć, a kutasik z guzikiem 20 gr. ${ }^{30}$ Podoficerowie mieli bardziej zdobne kapuzy. Wszelkie oblamowania oraz cyfry wykonywano z tasiemki „srebrem oblekanej" (czyli takiej, do produkcji której używano również nici srebrnych, metalizowanych), a ponadto obłóg obszywano za pomocą 2,5 łokcia galonu srebrnego „na jeden palec szerokiego". ${ }^{31} \mathrm{Na}$ wykonanie zdobień dla 6 takich przeznaczono 7 cywek $^{32}$ srebra po $8^{33}-9^{34}$ zł jedna. W 1754 r. i 1764 r. zakupiono 20 łokci pojedynczego srebrnego galonu oraz tyle samo "galonu wąskiego" na "cyfry”. ${ }^{35} \mathrm{~W}$ specyfikacji z 1762 r. wspomina się jedynie 26 łokci „galonu wąskiego na cyfry do kapuz” oraz nieznaną ilość galonu „srybrnego pojedynkowego szyrszego do munduru y kapuz dla unterofficerów". ${ }^{36} \mathrm{Z}$ kolei srebrny kutasik ${ }^{37}$ szacowano na 50 gr. $^{38}$ Wykonanie kapuz

48, Specyfykacya potrzeb należących do monduru wielkiego pro 1ma Augusti 1760 anno, któren podług zwyczaju daie się na latt dwie dla ludzi chorągwi piechoty węgierskiey buławy p[olnej] k[oron]ney potrzeba aby wcześnie były skupione te niżey opisane rzeczy, które się podaią, jaśnie wielmożnemu panu dobrodziejowi, Podhorce, 12 IV 1760 r., b.p.

30 Ibid., Podh IV/XLVII, plik 25, Specyfykacya małego moderunku..., 13 VII 1761 r., b.p.

31 Ibid., plik 13, Specyfikacja rekwizytów..., 29 III 1754 r., b.p.

32 Jednostka miary określająca wagę metalu (srebra lub złota) użytego w procesie produkcji pasmanterii z wykorzystaniem metalizowanych nici. Niestety nie udało się ustalić ile gram kruszcu przypadało na cywkę.

33 AN w Krakowie, AS, Ap, Podh IV/XLVII, plik 17, Rejestr percept y expens..., 11 IV 1754 r., b.p.

34 Ibid., plik 44, Regestr percepty y expensy dla ludzi chorągwi piechoty węgierskiey komputowey jaśnie wielmożnego pana wojewody krakowskiego, hetmana polnego koronnego a to na mondur wielki, dwoletni a die prima Augusti 1764 a[nno] należący, która percepta y expensa niżey się specyfikuie, [Podchorce], 27 VII 1764 r., b.p.; plik 59, Regestr percepty y expensy..., 13 XII 1766 r., b.p.

35 Ibid., plik 17, Rejestr percept y expens..., 11 IV 1754 r., b.p.; plik 44, Regestr percepty y expensy..., 27 VII 1764 r., b.p.

36 Ibid., Podh II 131, Specyfikacya rekwizytów dla chorągwi piechoty węgierskiey pana wojewody podolskiego hetmana polnego koronnego pro 1ma Augusti 1762 do barwy należących, które z Les[z]na wyprowadzone bydź maią, Podhorce, 21 IV 1762 r., 49.

37 Ibid., Podh IV/XLVII, plik 16, Ogułem [sic!] spisanych rzeczy dla chorągwi piechoty węgierskiey do wielkiego moderunku pro die 1ma Augusti Eodem anno należących, które w Brodach alboli w Chełmie sprawić się mogą, Podhorce, 29 III 1754 r., b.p.; plik 17, Rejestr percept y expens..., 11 IV 1754 r., b.p.

38 Ibid., Podh IV/L, plik 42, Specyfikacya potrzeb należących do monduru wielkiego pro d[ie] 1ma Augusti 1756 a[nn]o, które potrzeba nim sukna będą sprowadzone, aby wcześni było wygotowane y skupione dla chorągwi piechoty węgierskiey jaśnie wielmożnego 
kosztowało w 1754 r. 1 zł (30 miedzianych groszy) za podoficerskie nakrycie głowy i 15-19 gr za pozostałe. Później koszt sporządzenia kapuzy wzrósł do 1 zł bez rozróżnienia na podoficerskie i szeregowych. ${ }^{39} \mathrm{~W} 1768 \mathrm{r}$. kapuzy wykonywał kuśnierz Maciej z Podhorec, natomiast cyfry na nich wyszywał Matys Namiotnik z Brodów. ${ }^{40}$

Podobnie jak w przypadku piechoty autoramentu cudzoziemskiego także i „Węgrzy” w omawianym okresie stosowali zaplatanie włosów w harcapy (j. niem. die Haare - włosy, der Zopf - warkocz), czyli warkocz owijany następnie czarną taśmą. ${ }^{41} \mathrm{~W}$ związku z tym od żołnierzy wymagano zapuszczania długich włosów. Było to niezwykle trudne przy kontraktowym - zazwyczaj dwuletnim - okresie służby, dlatego też przynajmniej czterokrotnie - w okresie 1752-1758 sporządzono sztuczne harcapy z konopi dla całej kompani, ${ }^{42}$ a okazjonalnie także i w mniejszych ilościach. ${ }^{43}$ Koszt wykonania wynosił 15 gr. $^{44}$ Początkowo w 1752 r. podoficerowie mieli otrzymać

jm pana hetmana p[olnego] k[oronne]go, które potrzeby niżey się specyfikuią, Podhorce, 20 IV 1756 r., b.p.; plik 48, Specyfykacya potrzeb należących do monduru wielkiego..., 12 IV 1760 r., b.p.; Podh IV/XL, plik 20, Specyfikacya potrzeb do monduru wielkiego..., 24 IV 1758 r., b.p.

39 Ibid., Podh IV/XLVII, plik 17, Rejestr percept y expens..., 11 IV 1754 r., b.p.; plik 38, Specyfikacya potrzeb należących małego moderunku dla ludzi chorągwi piechoty węgierskiey komputowey pana Rzewuskiego wojewody krakowskiego, hetmana polnego koronnego pro prima Augusti 1763 a[nno] na rok cały aż do munduru wielkiego przypadającego prima Augusti 1764 a[nno], które potrzeby niżey się specyfikuią, Podhorce, 1 X 1763 r., b.p.; plik 44, Regestr percepty y expensy..., 27 VII 1764 r., b.p.; plik 59, Regestr percepty y expensy..., 13 XII 1766 r., b.p.; Podh IV/L, plik 42, Specyfikacya potrzeb należących do monduru wielkiego..., 20 IV 1756 r., b.p.; Podh IV/XL, plik 20, Specyfikacya potrzeb do monduru wielkiego..., 24 IV 1758 r., b.p.; Podh IV/L, plik 46, Specyfikacya decessu w mondurze przez dizerterów trzech uczyniony w Warszawie in [Novem] bri podczas Seymu 1760 a[nno], Podhorce, 30 XI 1760 r., b.p.; plik 48, Specyfykacya potrzeb należących do monduru wielkiego..., 12 IV 1760 r., b.p.

40 Ibid., Podh IV/XLVII, plik 85, Expens na mundur wielki..., 22 XI 1768 r., b.p.

${ }^{41} \quad$ Ibid., plik 17, Rejestr percept y expens..., 11 IV 1754 r., b.p.

42 Ibid.; plik 22, Regestr sprawienia barw na gemeinów sześciu, to iest na mieysce dwóch deserterów y iednego kadeta Ardelego, na trzech gemeinów do kompletu sześciudziesiąt do chorągwi piechoty węgierskiey buławy polney koronney, które sprawunki niżey się specyfikuią, Podhorce, 16 III 1753 r., b.p.; plik 23, Specyfikacya munderunku chorągwi..., 17 VII 1752 r., b.p.; Podh IV/L, plik 42, Specyfikacya potrzeb należących do monduru wielkiego..., 20 IV 1756 r., b.p.; Podh IV/XL, plik 20, Specyfikacya potrzeb do monduru wielkiego..., 24 IV 1758 r., b.p.

43 Ibid., Podh IV/L, plik 42, Specyfikacya potrzeb należących do monduru wielkiego..., 20 IV 1756 r., b.p.; Podh IV/XLVII, plik 22, Regestr sprawienia barw na gemeinów..., 16 III 1753 r., b.p.

44 Ibid., Podh IV/XLVII, plik 17, Rejestr percept y expens..., 11 IV 1754 r., b.p.; Podh IV/XL, plik 20, Specyfikacya potrzeb do monduru wielkiego..., 24 IV 1758 r., b.p. 
wstążki półjedwabne ${ }^{45}$ jednak od 1753 r. wstążki do harcapów dla wszystkich wykonywano z czarnej taśmy włóczkowej. Jej ilość się zmieniała, w 1753 r. przewidziano na jednego żołnierza 4 łokcie, następnie zwiększono ją do 6 łokci taśmy wydawanej przy okazji wielkiego munduru. ${ }^{46} \mathrm{~W} 1760 \mathrm{r}$. były to 4 łokcie, a od $1761 \mathrm{r}$. 3 łokcie. ${ }^{47}$ Cena za łokieć zmieniała się w omawianym czasie między 6 (w latach 1753-1754, 1756, 1758, 1760, 1766), 7,5 (1761) a 8 gr $(1755,1763)$, co świadczyć może o różnych właściwościach (szerokość?) zakupywanej taśmy do obwiązywania harcapów.48

Podstawowym elementem bielizny żołnierskiej były koszule. Każdy żołnierz otrzymywał dwie sztuki rocznie. Dla podoficerów, podobnie jak dla żołnierzy autoramentu cudzoziemskiego, koszule wykonywano z płótna lnianego. W 1753 r. na jedną koszulę przewidywano 4 arszyny płótna lnianego w cenie 26 gr, co wskazuje, iż była to tkanina lepszej jakości. ${ }^{49}$ Od 1754 r. podoficerowie nie otrzymywali już gotowych koszul, a jedynie ekwiwalent na ich wykonanie w kwocie 6 zł i 24 gr ${ }^{50}$, natomiast od 1755 r. 8 zł. ${ }^{51}$ Wyjątkowo w lipcu 1761 r., w związku z wysokimi cenami płótna,

\footnotetext{
45 Ibid., Podh IV/XLVII, plik 23, Specyfikacya munderunku chorągwi..., 17 VII 1752 r., b.p.
}

46 Ibid., Podh IV/L, plik 42, Specyfikacya potrzeb należących do monduru wielkiego..., 20 IV 1756 r., b.p.; Podh IV/XLVII, plik 17, Rejestr percept y expens..., 11 IV 1754 r., b.p.; plik 22, Regestr sprawienia barw na gemeinów..., 16 III 1753 r., b.p.; Podh IV/XL, plik 1, Specyfikacja drobnego moderunku..., 29 VII 1755 r., b.p.; plik 20, Specyfikacya potrzeb do monduru wielkiego..., 24 IV 1758 r., b.p.

47 Ibid., Podh IV/XLVII, plik 25, Specyfykacya małego moderunku..., 13 VII 1761 r., b.p.; plik 38, Specyfikacya potrzeb należących małego moderunku..., 1 X 1763 r., b.p.; plik 59, Regestr percepty y expensy..., 13 XII 1766 r., b.p.; jedynie w 1764 r. były to 4 łokcie (ibid., plik 44, Regestr percepty y expensy..., 27 VII 1764 r., b.p.).

48 Ibid., plik 11, Regestr percepty y expensy na drobny moderunek..., 8 IX 1753 r., b.p.; plik 17, Rejestr percept y expens..., 11 IV 1754 r., b.p.; plik 22, Regestr sprawienia barw na gemeinów..., 16 III 1753 r., b.p.; plik 25, Specyfykacya małego moderunku..., 13 VII 1761 r., b.p.; plik 38, Specyfikacya potrzeb należących małego moderunku..., 1 X 1763 r., b.p.; plik 44, Regestr percepty y expensy..., 27 VII 1764, b.p.; plik 59, Regestr percepty y expensy..., 13 XII 1766 r., b.p.; plik 85, Expens na mundur wielki..., 22 XI 1768 r., b.p.; Podh IV/XL, plik 1, Specyfikacja drobnego moderunku..., 29 VII 1755 r., b.p.; plik 20, Specyfikacya potrzeb do monduru wielkiego..., 24 IV 1758 r., b.p.; Podh IV/L, plik 42, Specyfikacya potrzeb należących do monduru wielkiego..., 20 IV 1756 r., b.p.; plik 46, Specyfikacya decessu w mondurze..., 30 XI 1760 r., b.p.; plik 48, Specyfykacya potrzeb należących do monduru wielkiego..., 12 IV 1760 r., b.p.

49 Ibid., Podh IV/XLVII, plik 11, Regestr percepty y expensy na drobny moderunek..., 8 IX 1753 r., b.p.; cena zwykłego płótna wynosiła 12-13 gr za łokieć.

50 Ibid., plik 1, Specyfikacya wiele ieszcze potrzeba na dalszą expens pieniędzy na zapłącenie rzemieśnikom niżey wyrażonym, Chełm, 16 IX 1754 r., b.p.

51 Ibid., Podh IV/XL, plik 1, Specyfikacja drobnego moderunku..., 29 VII 1755 r., b.p.; Podh IV/L, plik 42, Specyfikacya potrzeb należących do monduru wielkiego..., 20 IV 
podwyższono wypłatę gotowych pieniędzy na mały mundur do $13 \mathrm{zł} .^{52}$ W latach 1763-1768 kwota ta wahała się między 8 (1764), 9 (1766, 1767) a 12 zł (1763). ${ }^{53}$ Szeregowi otrzymywali koszule wykonane z "równego” płótna konopnego. Do 1754 r. było to 6 łokci lub 4 arszyny ${ }^{54}$, a następnie już 4,5 arszyna na jedną koszulę. ${ }^{55}$ Dla porównania w leibkompanii Regimentu Pieszego szefostwa Rzewuskiego stacjonującego w tym samym miejscu na koszule przeznaczano maksymalnie 4 arszyny płótna. ${ }^{56}$ Cena płótna do 1758 r. wynosiła po $15 \mathrm{gr}$ za arszyn, by w $1761 \mathrm{r}$. osiągnąć cenę 1 zł i 4 gr. ${ }^{57}$ Po kryzysie związanym z fałszowaniem polskiej monety cena arszyna płótna konopnego wynosiła około 20 gr. ${ }^{58}$ Wraz ze wzrostem ceny tkaniny rósł też koszt robocizny. Co najmniej do 1760 r. koszt uszycia

1756 r., b.p.; plik 48, Specyfykacya potrzeb należących do monduru wielkiego..., 12 IV 1760 r., b.p.; Podh IV/XL, plik 20, Specyfikacya potrzeb do monduru wielkiego..., 24 IV 1758 r., b.p.

52 Ibid., Podh IV/XLVII, plik 25, Specyfykacya małego moderunku..., 13 VII 1761 r., b.p.

53 Ibid., plik 25, Specyfykacya małego moderunku..., 13 VII 1761 r., b.p.; plik 38, Specyfikacya potrzeb należących małego moderunku..., 1 X 1763 r., b.p.; plik 44, Regestr percepty y expensy..., 27 VII 1764 r., b.p.; plik 59, Regestr percepty y expensy..., 13 XII 1766 r., b.p.; plik 71, Specyfikacya potrzeb należących..., 1768 r., b.p.

54 Ibid., plik 11, Regestr percepty y expensy na drobny moderunek..., 8 IX 1753 r., b.p.; plik 23, Specyfikacya munderunku chorągwi..., 17 VII 1752 r., b.p.

55 Ibid., Podh IV/XL, plik 1, Specyfikacja drobnego moderunku..., 29 VII 1755 r., b.p.; plik 20, Specyfikacya potrzeb do monduru wielkiego..., 24 IV 1758 r., b.p.; Podh IV/L, plik 48, Specyfykacya potrzeb należących do monduru wielkiego..., 12 IV 1760 r., b.p.; Podh IV/XLVII, plik 17, Rejestr percept y expens..., 11 IV 1754 r., b.p.; plik 25, Specyfykacya małego moderunku..., 13 VII 1761 r., b.p.; plik 44, Regestr percepty y expensy..., 27 VII 1764 r., b.p.

56 Ibid., Podh II 42, [Rachunki różne], b.m., 1757-1759, 1, 7-8, 12, 13, 17; Podh II 83, Specyfikacya wydatku z zostawionego płutna na kleinmundur pro An[n]o 1756 należącego arszeni 193 y ćw. 2 za dyspozyci WJmci porucznika Blikowskiego, Podhorce, [1756 r.], 74; Podh IV/III, plik 77, Specyfikacya rzeczy chorągwianych od leybkompaniey regimentu pieszego buławy polney koronney, Podhorce, 25 VI 1757 r., b.p.; Podh IV/XLIV, plik 46, Wydatek płutna [sic!] poczynaiący się a [die] 16 Septembris $1760 \mathrm{~A}$ [nn]o us[que] ad ultimam Juny An[n]o 1761 mo na różne potrzeby, [Podhorce], b.p.

57 Ibid., Podh IV/XLVII, plik 11, Regestr percepty y expensy na drobny moderunek..., 8 IX 1753 r., b.p.; plik 17, Rejestr percept y expens..., 11 IV 1754 r., b.p.; plik 25, Specyfykacya małego moderunku..., 13 VII 1761 r., b.p.; Podh IV/XL, plik 1, Specyfikacja drobnego moderunku..., 29 VII 1755 r., b.p.; plik 12, Specyfikacya szabel które dla chorągwi piechoty węgierskiey jw. pana hetmana polnego koronnego z rozkazu zkontraktowawszy rzemieślników w Staszowie, 1 II - 2 IV 1756 r., b.p.; Podh IV/L, plik 42, Specyfikacya potrzeb należących do monduru wielkiego..., 20 IV 1756 r., b.p.

58 Ibid., Podh IV/XLVII, plik 38, Specyfikacya potrzeb należących małego moderunku..., 1 X 1763 r., b.p.; plik 44, Regestr percepty y expensy..., 27 VII 1764 r., b.p.; plik 59, Regestr percepty y expensy..., 13 XII 1766 r., b.p. 
koszuli wynosił 8 gr $^{59} \mathrm{i}$ był porównywalny $\mathrm{z}$ wynagrodzeniem za wykonanie przez żony żołnierskie koszul w leibkompanii Regimentu Pieszego Buławy Polnej Koronnej w Podhorcach. ${ }^{60}$ Od 1761 r. wzrósł do 13 gr i utrzymał się co najmniej do $1768 \mathrm{r}^{61}$

Zwieńczeniem koszuli był halsztuk noszony na szyi. W 1752 r. dla 67 żołnierzy i podoficerów zamówiono 20 łokci czarnej krepy lnianej po tynfie (38-39 gr miedzianych) za łokieć. ${ }^{62}$ Później zamieniono krepę na czarne włóczkowe tasiemki wykonywane $\mathrm{z}$ wełny ${ }^{63} \mathrm{~W}$ specyfikacjach $\mathrm{z}$ lat 1763 1766 określono je ponadto jako „dychtowane”, czyli z niem. gęsto, grubo tkane. ${ }^{64}$ Taśmę zapinano przy pomocy mosiężnych klamerek. Koszt ich sporządzenia wynosił od 1752 r. 15 gr ${ }^{65}$ Dopiero po 1766 r. cena sporządzenia zapięcia do halsztuku zmniejszyła się do 12 gr za sztukę. ${ }^{66}$ Rachunki niejednoznacznie wskazują na detale konstrukcyjne. Ilość zamówionej czarnej krepy w 1752 r. (480 cali) sugeruje, że podobnie jak w leibkompanii sporządzano

59 Ibid., Podh IV/XL, plik 1, Specyfikacja drobnego moderunku..., 29 VII 1755 r., b.p.; plik 20, Specyfikacya potrzeb do monduru wielkiego..., 24 IV 1758 r., b.p.; Podh IV/XLVII, plik 1, Specyfikacya wiele ieszcze potrzeba..., 16 IX 1754 r., b.p.; plik 11, Regestr percepty y expensy na drobny moderunek..., 8 IX 1753 r., b.p.; Podh IV/L, plik 42, Specyfikacya potrzeb należących do monduru wielkiego..., 20 IV 1756 r., b.p.; wyjątkowo w 1753 r. zapłacono po 12 gr za uszycie 6 koszul po dezerterach; Podh IV/XLVII, plik 22, Regestr sprawienia barw na gemeinów..., 16 III 1753 r., b.p.

60 Ibid., Podh II 42, [Rachunki różne], b.m., [1758-1759], 7-8, 13, 17.

${ }^{61}$ Ibid., Podh IV/XLVII, plik 25, Specyfykacya małego moderunku..., 13 VII 1761 r., b.p.; plik 38, Specyfikacya potrzeb należących małego moderunku..., 1 X 1763 r., b.p.; plik 44, Regestr percepty y expensy..., 27 VII 1764 r., b.p.; plik 59, Regestr percepty y expensy..., 13 XII 1766 r., b.p.; plik 85, Expens na mundur wielki..., 22 XI 1768 r., b.p.

62 Ibid., plik 23, Specyfikacya munderunku chorągwi..., 17 VII 1752 r., b.p.

63 Ibid., Podh IV/XL, plik 20, Specyfikacya potrzeb do monduru wielkiego..., 24 IV 1758 r., b.p.; Podh IV/XLVII, plik 17, Rejestr percept y expens..., 11 IV 1754 r., b.p.

64 Ibid., Podh IV/XLVII, plik 38, Specyfikacya potrzeb należących małego moderunku..., 1 X 1763 r., b.p.; plik 44, Regestr percepty y expensy..., 27 VII 1764 r., b.p.; plik 59, Regestr percepty y expensy..., 13 XII 1766 r., b.p.

65 Ibid., Podh IV/XL, plik 1, Specyfikacja drobnego moderunku..., 29 VII 1755 r., b.p.; plik 20, Specyfikacya potrzeb do monduru wielkiego..., 24 IV 1758 r., b.p.; Podh IV/XLVII, plik 9, [Kwit na odebrane przez Franciszka Bałłę pieniądze], Podhorce, 16 V 1754 r., b.p.; plik 17, Rejestr percept y expens..., 11 IV 1754 r., b.p.; plik 22, Regestr sprawienia barw na gemeinów..., 16 III 1753 r., b.p.; plik 23, Specyfikacya munderunku chorągwi..., 17 VII 1752 r., b.p.; plik 25, Specyfykacya małego moderunku..., 13 VII 1761 r., b.p.; plik 38, Specyfikacya potrzeb należących małego moderunku..., 1 X 1763 r., b.p.; plik 44, Regestr percepty y expensy..., 27 VII 1764 r., b.p.; Podh IV/L, plik 46, Specyfikacya decessu w mondurze..., 30 XI 1760 r., b.p.

66 Ibid., Podh IV/XLVII, plik 59, Regestr percepty y expensy..., 13 XII 1766 r., b.p.; plik 85, Expens na mundur wielki..., 22 XI 1768 r., b.p. 
z niej 2 halsztuki mające po 3 cale szerokości. ${ }^{67}$ Przynajmniej raz, w 1753 r., fakt sporządzania dwóch halsztuków potwierdzono źródłowo. ${ }^{68}$ Niekompletność posiadanych rachunków i specyfikacji nie pozwala stwierdzić, czy po tej dacie halsztuki przydzielano co roku, czy jedynie przy okazji wydawania wielkiego munduru. ${ }^{69} \mathrm{~W} 1755$ i 1756 r. dla 70 osób zamówiono 74 łokcie czarnej taśmy, w 1763 r. było to 50 łokci, a w latach 1764-1767 miało to być już tylko 60 łokci taśmy. ${ }^{70}$ Dane te nie pozwalają na ustalenie, czym uzależniona była zmienna ilość przy dokonywanych zakupach. Być może miało to związek z szerokością takiej taśmy. W rachunku z 1763 r. jednoznacznie wskazano, że chodzi o taśmę „,rychtowaną, szeroką," której zamówiono jedynie 50 łokci. ${ }^{71}$ Płynność widzimy także w cenach przewidzianych dla gotowych halsztuków. W 1753 r. kosztowały one po 8 gr, w 1754 r. już 15 gr, rok później 10 gr, a w latach $1758-1761$ po 13 gr. $^{72}$ Od 1764 r. czarną, rychtowaną taśmę na halsztuki wyceniano na $24 \mathrm{gr}^{73}$

Suknia wierzchnia piechoty węgierskiej, zwana także katanką, wykonana była z 4 łokci sukna krabrotowego, czyli czerwonego uzyskiwanego za pomocą farbowania marzanną barwierską, inaczej krapem (z niem. Krapp), „czterdziestowego” (dla podoficerów) lub „trzydziestowego” (dla

67 Ibid., Podh IV/XLIV, plik 90, Dokumenta ludzi z Kamieńca przysła[n]ych do Podhorec r. 1763, Kamieniec Podolski, 1762-1764, b.p.; Podh II 263, Obiaśnienie regulaminu woyska pieszego koronnego 1717 Anni, b.m., [1760 r.], \$ 8, b.p.; Podh IV/II, plik 10, [Specyfikacja umundurowania na unterofficera], b.m., [1762 r.], b.p.; Podh III, pudło IX/III, plik 14, Specyfikacya odebranego moderunku na chorągiew JWM pana major A. Fresse, Brody, 7 II 1749 r., b.p.; Podh III, pudło V/1, plik 3, [Specyfikacja] na dwie chorągwie regimentu pieszego Jaśnie oświeconego JW. pana kasztelana krakowskiego hetmana wielkiego koronnego w garnizonie stanisławowskim zostaiące, tak sukna iako y inne do wielkiego mondyrynku należące niżey specyfikuią się rzeczy, sprowadzone y oddane przez Jakoba Krajewskiego foryera pomienionego regim[en]tu, Stanisławów, 14 II 1749 r., b.p.

68 Ibid., Podh IV/XLVII, plik 11, Regestr percepty y expensy na drobny moderunek..., 8 IX 1753 r., b.p.

69 Ibid., Podh IV/XL, plik 1, Specyfikacja drobnego moderunku..., 29 VII 1755 r., b.p.

70 Ibid., Podh IV/XLVII, plik 17, Rejestr percept y expens..., 11 IV 1754 r., b.p.; plik 38, Specyfikacya potrzeb należących małego moderunku..., 1 X 1763 r., b.p.; plik 44, Regestr percepty y expensy..., 27 VII 1764 r., b.p.; plik 59, Regestr percepty y expensy..., 13 XII 1766 r., b.p.

71 Ibid., plik 38, Specyfikacya potrzeb należących małego moderunku..., 1 X 1763 r., b.p.

72 Ibid., Podh IV/XL, plik 1, Specyfikacja drobnego moderunku..., 29 VII 1755 r., b.p.; plik 20, Specyfikacya potrzeb do monduru wielkiego..., 24 IV 1758 r., b.p.; Podh IV/XLVII, plik 11, Regestr percepty y expensy na drobny moderunek..., 8 IX 1753 r., b.p.; plik 17, Rejestr percept y expens..., 11 IV 1754 r., b.p.; plik 25, Specyfykacya małego moderunku..., 13 VII 1761, b.p.; plik 59, Regestr percepty y expensy..., 13 XII 1766 r., b.p.

73 Ibid., Podh IV/XLVII, plik 44, Regestr percepty y expensy..., 27 VII 1764 r., b.p.; plik 59, Regestr percepty y expensy..., 13 XII 1766 r., b.p. 
szeregowych). ${ }^{74} \mathrm{~W}$ latach sześćdziesiątych XVIII w. katanka uległa pewnemu skróceniu, gdyż zmniejszono ilość czerwonego sukna na mundur z 5 łokci do ok. 4,5. ${ }^{75}$ Podszywano go „szerokim i dychtowanym” szafirowym kirem oraz płótnem konopnym. ${ }^{76} \mathrm{~W} 1752$ r. przewidziano po 4,5 łokcia kiru na mundur, w 1754 r. 5,5 łokcia, od 1764 r. jego ilość się zmniejszała do 4,25 łokcia, a następnie do 4 łokci dwa lata później. ${ }^{77}$ Razem z redukcją ilości materiału podszewkowego da się zauważyć zmniejszenie ilości sukna szafirowego i kaprotowego. ${ }^{78}$ Natomiast na pełny mundur przewidywano przez cały omawiany okres po 5 arszynów płótna. ${ }^{79}$ Katanki nie posiadały rabatów, czyli klap lub wyłogów, a jedynie obszlegi (z niem. Aufschlägen), czyli mankiety. ${ }^{80}$ Jak pokazują grafiki, mankiety miały formę węgierską w kolorze szafirowym. Portret Franciszka Bałły - rotmistrza chorągwi - ukazuje również niewielki wykładany kołnierz, lecz w źródłach pisanych brak jakichkolwiek informacji pozwalających potwierdzić występowanie tego elementu w mundurze podoficerów i szeregowych. ${ }^{81}$ Prawdopodobnie "katanki wierzchnie”, czyli suknie, były krojone $\mathrm{w}$ ten sposób, iż plecy (w przeciwieństwie do

74 Ibid., Podh IV/XLVII, plik 13, Specyfikacja rekwizytów..., 29 III 1754 r., b.p.; plik 22, Regestr sprawienia barw na gemeinów..., 16 III 1753 r., b.p.; plik 23, Specyfikacya munderunku chorągwi..., 17 VII 1752 r., b.p.; plik 59, Regestr percepty y expensy..., 13 XII 1766 r., b.p.

75 Ibid., plik 59, Regestr percepty y expensy..., 13 XII 1766 r., b.p.

76 Ibid., Podh IV/XL, plik 1, Specyfikacja drobnego moderunku..., 29 VII 1755 r., b.p.

77 Ibid., Podh IV/XLVII, plik 13, Specyfikacja rekwizytów..., 29 III 1754 r., b.p.; plik 23, Specyfikacya munderunku chorągwi..., 17 VII 1752 r., b.p.; plik 44, Regestr percepty y expensy..., 27 VII 1764 r., b.p.; Podh IV/L, plik 46, Specyfikacya decessu w mondurze..., 30 XI 1760 r., b.p.

78 Ibid., Podh IV/XLVII, plik 44, Regestr percepty y expensy..., 27 VII 1764 r., b.p.; plik 59, Regestr percepty y expensy..., 13 XII 1766 r., b.p.

79 Ibid., Podh IV/L, plik 42, Specyfikacya potrzeb należących do monduru wielkiego..., 20 IV 1756 r., b.p.; plik 48, Specyfykacya potrzeb należących do monduru wielkiego..., 12 IV 1760 r., b.p.; Podh IV/XLVII, plik 17, Rejestr percept y expens..., 11 IV 1754 r., b.p.; plik 44, Regestr percepty y expensy..., 27 VII 1764 r., b.p.; plik 59, Regestr percepty y expensy..., 13 XII 1766 r., b.p.; Podh IV/ XL, plik 20, Specyfikacya potrzeb do monduru wielkiego..., 24 IV 1758 r., b.p.

80 Obszlegi, czyli spolszczona nazwa niem. Aufschlägen - stosowana była w XVIII w. tylko do mankietów; dowodzi tego m.in. użycie tego zwrotu w stosunku do elementów umundurowania w których klapy nie występowały np. kolet skórzany (AN w Krakowie, AS, Ap, Podh I 134, Regestr rzeczy po zmarłym jp pana kapitanie Grotowskim Regimentu Buławy Polney Koronney przez Pana Wjci pana Grotowskiego podstolego y sędziego sochaczewskiego wydanych a przez pana kapitana Brodowskiego iako plenipotenta Regimentu pomienionego odebranych w Grotowicach, 28 VI 1759 r., 125, 135, 149); również w j. niemieckim klapy zawsze odróżniano od obszlegów, zob. Hans Bleckwenn, Die Ökonomie-Reglements des Altpreussische Heeres (Osnabrück: Biblio Verlag, 1973).

81 Muzeum Narodowe w Warszawie (dalej: MN w Warszawie), Portret Franciszka Bałły, MP 2445 MNW, 5622 Tc 75, b.m., ok. 1765 r., https://cyfrowe.mnw.art.pl/pl/katalog/508531, dostęp kwiecień 6, 2021; Podhorce, 72, obraz nr 539, kat. A.148. 
mody polskiej i węgierskiej) składały się z dwóch elementów, co ułatwiało wywijanie połów i formowanie „fałd”, o których wspomina się w kilku miejscach, między połami pleców i przodku. ${ }^{82}$

$\mathrm{Z}$ przodu katanki zapinane były na guziki na szamerowaniu wykonanym $\mathrm{z}$ białego włóczkowego sznurka, a u podoficerów ze sznurka srebrnego. Guziki przewlekano bezpośrednio przez pętlice tworzone na zakończeniu szamerowania, które prowadzono od centka, czyli półguzika, aż do krawędzi sukni wierzchniej z obu jej stron. Ustalenie dokładnej ilości łokci sznurka przeznaczonego na szamerowanie jest niestety trudne. W specyfikacji z 1754 r. dla 6 podoficerów przewidziano 385 łokci srebrnego sznurka pod mundur podoficerski i na kapuzy, natomiast dla szeregowych za pasy włóczkowe, tasiemki, węzły i oblamowania kapuz szmuklerz ${ }^{83}$ określił cenę po $11 \mathrm{zł}$ od żołnierza. ${ }^{84} \mathrm{~W} 1761 \mathrm{r}$. dla szeregowego podano ilość sznurka pod mundur i kapuzy na 50 łokci. ${ }^{85} \mathrm{Na}$ początku 1752 r. do katanki i żupanika przeznaczano łącznie po 30 guzików i 60 "centków" ${ }^{86}$ Guziki miały formę "dentych" ${ }^{37}$ (pustych w środku) węgierskich guzów ${ }^{88}$ wykonanych z cyny. ${ }^{89}$ Od 1753 r. liczbę guzików zmniejszono do ok. tuzina na suknię wierzchnią i tyleż samo na żupanik..$^{90}$ Nie da się wykluczyć, że jakieś inne guziki przeznaczano na mankiety (po jednym) i zamknięcie taszek kieszennych widocznych na rycinie G.N. Raspego. ${ }^{91}$ Na podstawie ceny za tuzin guzików wraz z dwoma tuzinami centków wynoszącej 3 zł możemy domniemywać, że co najmniej do 1768 r. liczba guzików nie uległa zmianie. ${ }^{92}$ Guziki mocowano w ten sposób, że stopkę

${ }^{82}$ AN w Krakowie, AS, Ap, Podh IV/XLVII, plik 44, Regestr percepty y expensy..., 27 VII 1764 r., b.p.

83 Rzemieślnik zajmujący się produkcją pasmanterii.

${ }^{84}$ AN w Krakowie, AS, Ap, Podh IV/XLVII, plik 17, Rejestr percept y expens..., 11 IV 1754 r., b.p.

85 Ibid., plik 25, Specyfykacya małego moderunku..., 13 VII 1761 r., b.p.

86 Ibid., plik 23, Specyfikacya munderunku chorągwi..., 17 VII 1752 r., b.p.

87 Ibid., Podh IV/L, plik 42, Specyfikacya potrzeb należących do mondoru wielkiego..., 20 IV 1756 r., b.p.

88 Ibid., Podh IV/XLVII, plik 22, Regestr sprawienia barw na gemeinów..., 16 III 1753 r., b.p.

89 Ibid., plik 16, Ogułem [sic!] spisanych rzeczy..., 29 III 1754 r., b.p.

90 Ibid., Podh IV/XL, plik 1, Specyfikacja drobnego moderunku..., 29 VII 1755 r., b.p.; Podh IV/XLVII, plik 22, Regestr sprawienia barw na gemeinów..., 16 III 1753 r., b.p.

91 Raspe, Accurate, tab. 47 i 48.

92 AN w Krakowie, AS, Ap, Podh IV/XLVII, plik 17, Rejestr percept y expens..., 11 IV 1754 r., b.p.; plik 25, Specyfykacya małego moderunku..., 13 VII 1761 r., b.p.; plik 59, Regestr percepty y expensy..., 13 XII 1766 r., b.p.; plik 85, Expens na mundur wielki..., 22 XI 1768 r., b.p.; Podh IV/XL, plik 20, Specyfikacya potrzeb do monduru wielkiego..., 24 IV 1758 r., b.p. 
przewlekano na drugą stronę materiału i przewlekano przez nią materiał: „irszane skórki” ${ }^{93}$ bądź płótno ${ }^{94}$.

Piechota węgierska prócz sukien wierzchnich otrzymywała także kitle. Noszono je latem zamiast sukni wierzchnich lub do prac gospodarczych „szanując barwy” albo na mundurze w trakcie niepogody i deszczu. W odróżnieniu od kitli noszonych przez Regiment Pieszy Buławy Polnej Koronnej, do których stosowano drelich lub płótno lniane, te wykonywano z grubego płótna konopnego. Pęczniało ono podczas deszczu i chroniło szczelnie mundur znajdujący się pod spodem. Z kolei latem kitel konopny pozbawiony podszewki lepiej oddawał nadmiar ciepła niż sukienna katanka podszyta wełnianym materiałem. Na jednego szeregowego zużywano 4,5 arszyna płótna konopnego materiału. ${ }^{95} \mathrm{~W}$ latach $1753-1760$ koszt sporządzenia kitlów wynosił 20 gr za sztukę. ${ }^{96} \mathrm{~W}$ latach $1761-1763$ koszt robocizny wzrósł do 26 gr, a od 1764 do 1766 r. wynosił 25 gr. ${ }^{97}$ Według specyfikacji z 22 listopada 1768 r. na sporządzenie 69 kitli w Olesku przewidziano kwotę 46 zł (po 20 gr za sztukę). ${ }^{98}$ Cena arszyna płótna konopnego była poza rokiem $1761 \mathrm{r}$. stosunkowo stała i wahała się między 14 a 16 gr. Rolę kitli u podoficerów spełniały płaszcze sukienne.

93 Ibid., Podh IV/XLVII, plik 17, Rejestr percept y expens..., 11 IV 1754 r., b.p.; plik 23, Specyfikacya munderunku chorągwi..., 17 VII 1752 r., b.p.; Podh IV/L, plik 42, Specyfikacya potrzeb należących do monduru wielkiego..., 20 IV 1756 r., b.p.; plik 48, Specyfykacya potrzeb należących do monduru wielkiego..., 12 IV 1760 r., b.p.; Podh IV/XL, plik 20, Specyfikacya potrzeb do monduru wielkiego..., 24 IV 1758 r., b.p.

94 Ibid., Podh IV/XLVII, plik 17, Rejestr percept y expens..., 11 IV 1754 r., b.p.

95 Ibid., Podh IV/XL, plik 1, Specyfikacja drobnego moderunku..., 29 VII 1755 r., b.p.; Podh IV/XLVII, plik 17, Rejestr percept y expens..., 11 IV 1754 r., b.p.; plik 25, Specyfykacya małego moderunku..., 13 VII 1761 r., b.p.; plik 44, Regestr percepty y expensy..., 27 VII 1764 r., b.p.; Podh IV/L, plik 42, Specyfikacya potrzeb należących do monduru wielkiego..., 20 IV 1756 r., b.p.; plik 48, Specyfykacya potrzeb należących do monduru wielkiego..., 12 IV 1760 r., b.p. Jedynie wg specyfikacji z 1766 r. na żołnierza przewidziano 5 arszynów (Podh IV/XLVII, plik 59), choć już w 1768 r. za 64 kitle wygospodarowano łącznie 2 zł i 20 gr, czyli 20 gr robocizny i 4 arszyny po 15 gr (Podh IV/XLVII, plik 71).

96 Ibid., Podh IV/XLVII, plik 1, Specyfikacya wiele ieszcze potrzeba..., 16 IX 1754 r., b.p.; plik 17, Rejestr percept y expens..., 11 IV 1754 r., b.p.; Podh IV/XL, plik 1, Specyfikacja drobnego moderunku..., 29 VII 1755 r., b.p.; plik 20, Specyfikacya potrzeb do monduru wielkiego..., 24 IV 1758 r., b.p.; Podh IV/L, plik 42, Specyfikacya potrzeb należących do monduru wielkiego..., 20 IV 1756 r., b.p.; plik 48, Specyfykacya potrzeb należących do monduru wielkiego..., 12 IV 1760 r., b.p.

97 Ibid., Podh IV/XLVII, plik 25, Specyfykacya małego moderunku..., 13 VII 1761 r., b.p.; plik 38, Specyfikacya potrzeb należących małego moderunku..., 1 X 1763 r., b.p.; plik 44, Regestr percepty y expensy..., 27 VII 1764 r., b.p.; plik 59, Regestr percepty y expensy..., 13 XII 1766 r., b.p.

98 Ibid., plik 85, Expens na mundur wielki..., 22 XI 1768 r., b.p. 
Rolę kamizelki u „Węgrów” pełnił żupanik, zwany także katanką spodnią. Wykonywano go z sukna szafirowego. Z wyglądu przypominał huzarski dołman, czyli krótką kurtkę zapinaną na rząd guzów i pętlic wykonanych ze sznurka. Jak wskazuje na to portret rotmistrza Franciszka Bałły, żupanik miał niewielki sterczący kołnierzyk-stójkę. ${ }^{99}$ Posiadamy zaledwie kilka wskazówek konstrukcyjnych pozwalających rekonstruować wygląd katanki spodniej. Wiemy, że jej przód podszywany był kirem szafirowym, ${ }^{100}$ a reszta płótnem konopnym. ${ }^{101}$ Zdarzały się przypadki podszywania całości płótnem - tak uczyniono m.in. z żupanikami sporządzonymi dla rekrutów w zastępstwie żupaników skradzionych przez dezerterów. Zużyto wówczas po 3 arszyny na kapuzy $(0,5)$ i katanki spodnie $(2,5) .{ }^{102} \mathrm{Z}$ kolei w $1761 \mathrm{r}$. pod żupaniki zużyto już tylko 2 arszyny płótna. ${ }^{103}$ Nie wiemy, czy wynikało to ze skrócenia katanek spodnich, czy raczej z wykorzystania do ich podszycia zapasów kiru szafirowego, którego nie wymieniono podobnie jak sukna czerwonego na 6 sporządzonych w tym samym czasie katanek wierzchnich.

Prawdopodobnie żupaniki posiadały długie rękawy, na co wskazuje spora ilość materiału przeznaczanego na ich sporządzenie - około 2,5 - 2 i 5/8 łokcia sukna, pomimo iż były zdecydowanie krótsze niż np. kamizelki piechoty autoramentu cudzoziemskiego, na które przeznaczano 1 łokieć sukna. ${ }^{104}$ Przód był - podobnie jak w katankach wierzchnich - szamerowany, z guzikami w tej samej ilości co na sukni wierzchniej, która w 1752 r. wynosiła 15 sztuk, a od 1753 r. tuzin oraz dwukrotność tej liczby centków. ${ }^{105}$ Ponadto żupaniki posiadały haftki. ${ }^{106} \mathrm{~W}$ żupanikach węgierskich $\mathrm{w}$ tym

99 MN w Warszawie, Portret Franciszka Bałły, MP 2455 MNW, 5622 Tc 75, b.m., ok. 1765 r.; Podhorce, obraz A.148, b.n.s.

100 AN w Krakowie, AS, Ap, Podh IV/XLVII, plik 13, Specyfikacja rekwizytów..., 29 III 1754 r., b.p.

101 Ibid., Podh IV/XL, plik 1, Specyfikacja drobnego moderunku..., 29 VII 1755 r., b.p.; Podh IV/XLVII, plik 25, Specyfykacya małego moderunku..., 13 VII 1761 r., b.p.

102 Ibid., Podh IV/XL, plik 1, Specyfikacja drobnego moderunku..., 29 VII 1755 r., b.p.

103 Ibid., Podh IV/XLVII, plik 25, Specyfykacya małego moderunku..., 13 VII 1761 r., b.p.

104 Ibid., Podh IV/XL, plik 1, Specyfikacja drobnego moderunku..., 29 VII 1755 r., b.p.; Podh IV/XLVII, plik 22, Regestr sprawienia barw na gemeinów..., 16 III 1753 r., b.p.; plik 23, Specyfikacya munderunku chorągwi..., 17 VII 1752 r., b.p.

105 Ibid., Podh IV/XLVII, plik 22, Regestr sprawienia barw na gemeinów..., 16 III 1753 r., b.p.; Podh IV/XL, plik 1, Specyfikacja drobnego moderunku..., 29 VII 1755 r., b.p.

106 Ibid., Podh IV/XLVII, plik 23, Specyfikacya munderunku chorągwi..., 17 VII 1752 r., b.p. Specyfikacje wymieniają także generalnie "haftki pod mundur”; AN w Krakowie, AS, Ap, Podh IV/XL, plik 20, Specyfikacya potrzeb do monduru wielkiego..., 24 IV 1758 r., b.p.; Podh IV/XLVII, plik 38, Specyfikacya potrzeb należących małego moderunku..., 1 X 1763 r., 


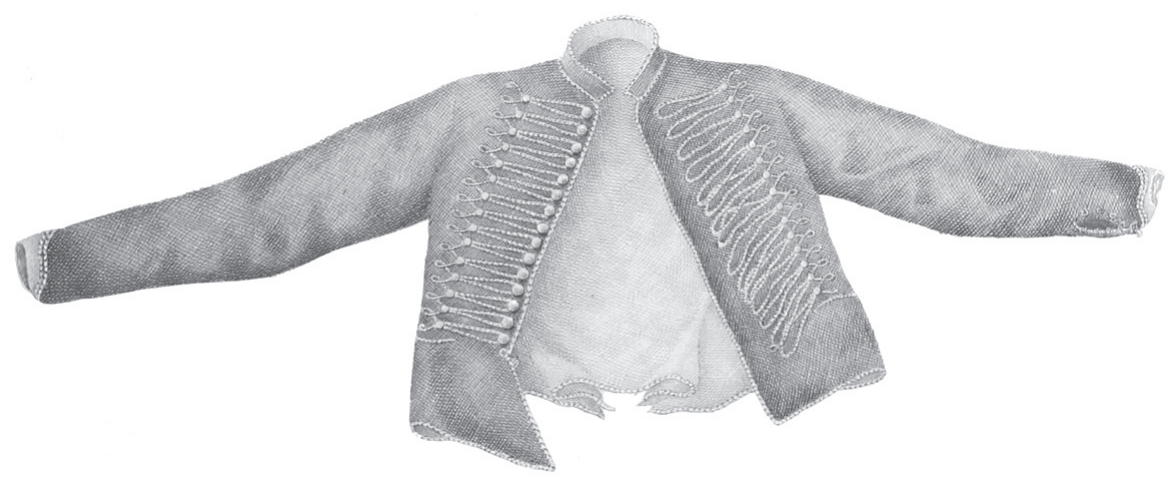

Ryc. 1. Dołman węgierski. Źródło: ÖStA/KA, BS L IV, 32, „Allgemeiner Aufriss”, Dritten Theils, Erster Abschnitt, fot. J. Hofman

okresie umieszczano je na zakończeniach rękawów i na końcu szamerowania. Dla austriackich dołmanów dla huzarów przewidywano 12 par haftek - 10 pod rękawy i 2 na zapięcia szamerowania. ${ }^{107}$

Charakterystyczną cechą munduru węgierskiego były długie, wąskie spodnie sięgające do kostek. Spodnie takie nosiły regimenty węgierskie w armii austriackiej i krojem przypominały one współczesne portki góralskie (z których te ostatnie się wywodzą). ${ }^{108}$ Spodnie te $\mathrm{z}$ przodu, dzięki klapce, przypominały tylko $\mathrm{z}$ grubsza pludry noszone $\mathrm{w}$ autoramencie cudzoziemskim. Krojone były z dwóch elementów - obu boków, których szew łączył nogawki na tyle. ${ }^{109} \mathrm{~W}$ chorągwi hetmana polnego na jedną parę

b.p.; plik 59, Regestr percepty y expensy..., 13 XII 1766 r., b.p.; plik 85, Expens na mundur wielki..., 22 XI 1768 r., b.p.

107 Österreichischen Staatsarchiv-Kriegsarchiv w Wiedniu (dalej: ÖStA/KA), Bildersammlung und Audiovsuellesammlungen, Uniformen (dalej: BS L IV), 32, „Allgemeiner Aufriss und Beschreibungen Sammentlicher Montours- und Rüstungs-Gattungen, Feld Requisiten und Kriegs Gerätschaften für die kaiserliche königliche Truppen zu Fuss und zu Pferd," Dritten Theil, Erster Abschnitt, b.m., [ca. 1768-1773], 45 oraz ryciny, rkps; Szabó Csabáné, Egy 18. századi férfi öltözet restaurálása, dostęp kwiecień 6, 2021, http://www. egrivar.hu/dobo-istvan-varmuzeum/szakmai-munka/blog/421-18-szazadi-ferfi-oltozet-res tauralasa?fbclid=IwAR0t4ojZ2SNAaSBPeH-it5iNvVbidgNQ3hFcOWee2kA8volqmyycQSjedzU].

108 ÖStA/KA, BS L IV, 32, „Allgemeiner Aufriss..., Zwölfter Theil, b.m., [ca. 1769-1773], 33-35 wraz z ryciną, rkps.

109 Eva Hottó, „Dekonstrukció és rekonstrukcióa XVII-XVIII. Századi magyar férfi öltözetek jellemző szabásformáinak rekonstrukciós elemzése," praca doktorska, Nyugat-Magyarországi Egyetem, Sopron 2014, 74-80, mps. 
spodni używano po 2 łokcie ${ }^{110}$ sukna szafirowego, lepszego dla podoficerów („czterdziestowego” w cenie 6-8 zł) i gorszego dla szeregowych (po 3 zł i 20 gr). ${ }^{111} \mathrm{Z}$ przodu znajdowała się klapka, której rozporki zdobiono sznurkiem - białym, włóczkowym u szeregowych i do 1753 r. kaprali i felczera, lub posrebrzanym u wachmistrza i podchorążego, a od $1754 \mathrm{r}$. u wszystkich podoficerów, a zapinano za pomocą haftek. ${ }^{112}$ Zapewne możemy w tym rozwiązaniu dostrzegać pierwotną wersję góralskich parzenic (ozdobnych wzorów). Sznurek ten stanowił zdobienie również na szwach zewnętrznych, tak wyraziście podkreślonych na późniejszych rycinach Raspego. ${ }^{113}$ Zmieniająca się ilość stosowanego do zdobienia spodni sznurka wskazuje, iż „szamerunek" wzbogacano (nawet do 12 łokci) lub zubażano (8-10 łokci) w zależności od możliwości finansowych kompanii. ${ }^{114}$

Tabela 1. Ilość zużytej pasmanterii na obszycie spodni podoficerów i szeregowych w latach 1753-1767

\begin{tabular}{|l|c|c|c|c|c|}
\hline \multicolumn{1}{|c|}{ Spodnie } & $\begin{array}{c}\text { wrzesień } \\
\mathbf{1 7 5 3}\end{array}$ & $\mathbf{1 7 5 5}$ & $\mathbf{1 7 6 1}$ & $\mathbf{1 7 6 3}$ & 1767 \\
\hline Sznurki srebrne & 8 łokci & 10 łokci & 10 łokci & 9 łokci & 10 łokci \\
\hline Sznurki białe & 8 łokci & 10 łokci & 12 łokci & 9 łokci & 8 łokci \\
\hline Cena za łokieć & $2 \mathrm{gr}$ & $2 \mathrm{gr}$ & $2,5 \mathrm{gr}$ & $1,5 \mathrm{gr}$ & $1,5 \mathrm{gr}$ \\
\hline
\end{tabular}

Źródło: oprac. własne autora na podstawie AN w Krakowie, AS, Ap, Podh IV/XLVII, pliki: 11, 25, 38, 71; Podh IV/XL, plik 1.

\footnotetext{
110 AN w Krakowie, AS, Ap, Podh IV/XLVII, plik 11, Regestr percepty y expensy na drobny moderunek..., 8 IX 1753 r., b.p.; plik 38, Specyfikacya potrzeb należących małego moderunku..., 1 X 1763 r., b.p.; w 1755 r. na wykonanie spodni przeznaczono po 2 łokcie i 1 ćwierć sukna, co wskazuje na węższą szerokość zastosowanej tkaniny; Podh IV/XL, plik 1, Specyfikacja drobnego moderunku..., 29 VII 1755 r., b.p.; Podh IV/XLVII, plik 71, Specyfikacya potrzeb należących..., 1768 r., b.p.

111 Ibid., Podh IV/XLVII, plik 11, Regestr percepty y expensy na drobny moderunek..., 8 IX 1753 r., b.p.; plik 22, Regestr sprawienia barw na gemeinów..., 16 III 1753 r., b.p.; plik 38, Specyfikacya potrzeb należących małego moderunku..., 1 X 1763 r., b.p.; plik 71, Specyfikacya potrzeb należących..., 1768 r., b.p.; Podh IV/XL, plik 1, Specyfikacja drobnego moderunku..., 29 VII 1755 r., b.p.

112 Ibid., Podh IV/XLVII, plik 11, Regestr percepty y expensy na drobny moderunek..., 8 IX 1753 r., b.p.

113 Raspe, Accurate, tab. 47.

114 AN w Krakowie, AS, Ap, Podh IV/XLVII, plik 11, Regestr percepty y expensy na drobny moderunek..., 8 IX 1753 r., b.p.; plik 25, Specyfykacya małego moderunku..., 13 VII 1761 r., b.p.; plik 71, Specyfikacya potrzeb należących..., 1768 r., b.p.; Podh IV/XL, plik 1, Specyfikacja drobnego moderunku..., 29 VII 1755 r., b.p.
} 


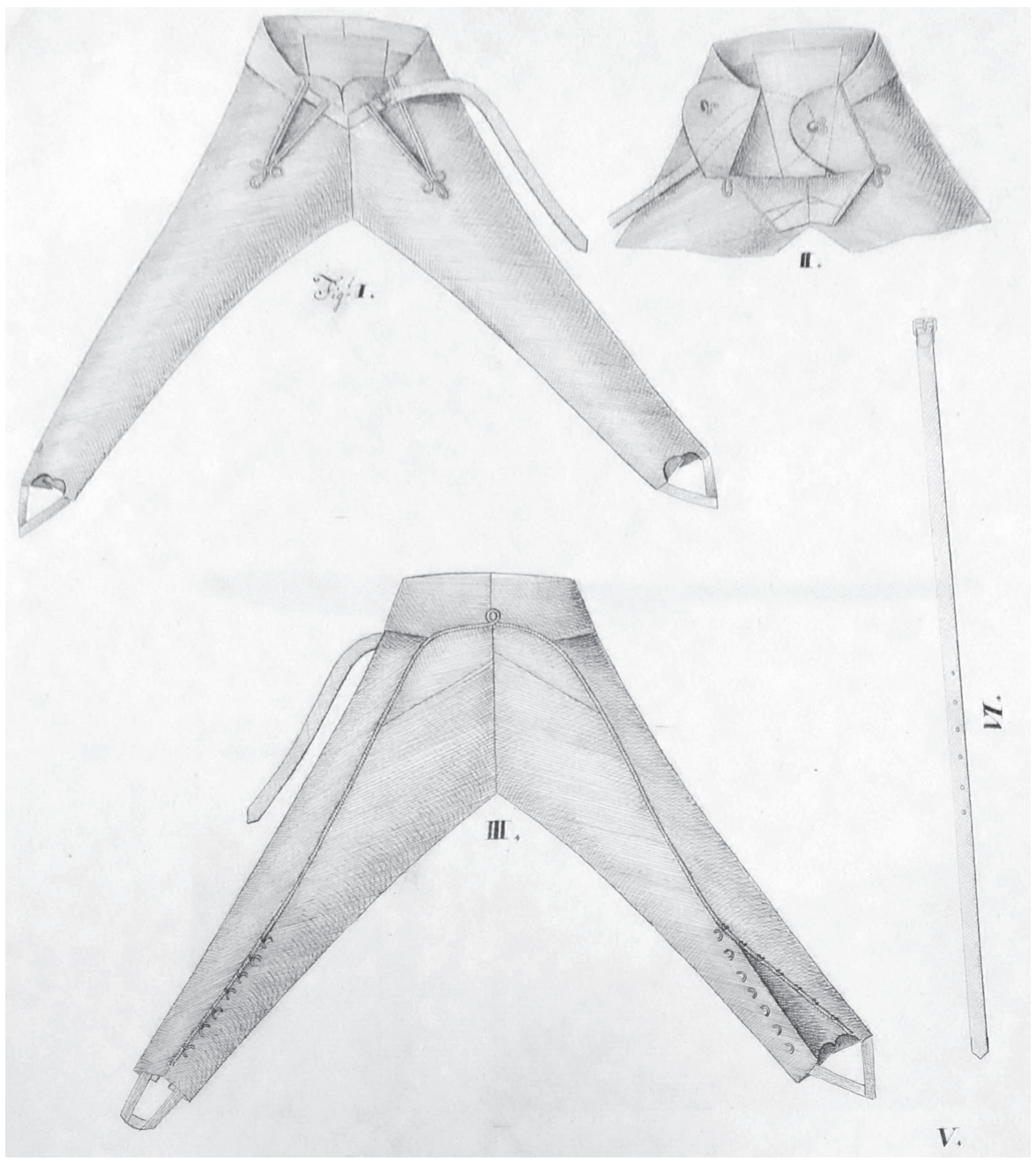

Ryc. 2. Spodnie węgierskie.

Źródło: ÖStA/KA, BS L IV, 32, „Allgemeiner Aufriss..., Zwölfter Theil, fot. J. Hofman

Spodnie te zapinane były na skórzany („rzemienny”) pasek ze sprzączką. ${ }^{115}$ Cena paska do spodni ze sprzączką wynosiła do 1760 r. 15 gr, następnie osiągnęła w 1761 r. rekordową cenę 26 gr, by następnie spaść do 19,5-18 gr w latach 1763-1764 i 15 gr w 1766 r. Poniższa tabela wskazuje, iż paski zakupywano dla wszystkich żołnierzy przy okazji wielkiego munduru, natomiast deces, czyli ubytki pojawiające się w wyniku dezercji,

115 Ibid., Podh IV/XLVII, plik 25, Specyfykacya małego moderunku..., 13 VII 1761 r., b.p.; plik 85, Expens na mundur wielki..., 22 XI 1768 r., b.p; ÖStA/KA, BS L IV, 32, „Allgemeiner Aufriss..., Zwölfter Theil, b.m., [ca. 1769-1773], 33, rkps. 
uzupełniano przy okazji zakupów „małego munduru” po wyższych cenach. Niestety brak kompletu dokumentów, prezentujących zakupy dokonywane w ramach „małego munduru”, nie pozwala na pełne określenie potrzeb chorągwi w zakresie zaopatrzenia w ten element.

Tabela 2. Ceny sporządzenia pasów skórzanych do spodni w latach 17561766

\begin{tabular}{|l|c|c|c|c|c|c|c|}
\hline & 1756 & 1758 & 1760 & 1761 & 1763 & 1764 & 1766 \\
\hline $\begin{array}{l}\text { Rodzaj } \\
\text { dokumentu }\end{array}$ & $\begin{array}{c}\text { Wielki } \\
\text { mundur }\end{array}$ & $\begin{array}{c}\text { Wielki } \\
\text { mundur }\end{array}$ & $\begin{array}{c}\text { Mały } \\
\text { mundur }\end{array}$ & $\begin{array}{c}\text { Mały } \\
\text { mundur }\end{array}$ & $\begin{array}{c}\text { Mały } \\
\text { mundur }\end{array}$ & $\begin{array}{c}\text { Wielki } \\
\text { mundur }\end{array}$ & $\begin{array}{c}\text { Wielki } \\
\text { mundur }\end{array}$ \\
\hline $\begin{array}{l}\text { Koszt } \\
\text { za sztukę }\end{array}$ & $15 \mathrm{gr}$ & $15 \mathrm{gr}$ & $15 \mathrm{gr}$ & $26 \mathrm{gr}$ & $19,5 \mathrm{gr}$ & $18 \mathrm{gr}$ & $15 \mathrm{gr}$ \\
\hline Liczba szt. & 70 & 70 & 70 & 10 & 10 & 70 & 70 \\
\hline
\end{tabular}

Źródło: oprac. własne autora na podstawie AN w Krakowie, AS, Ap, Podh IV/XLVII, pliki: 25, 38, 44, 59; Podh IV/XL, plik 20; Podh IV/L, pliki: 42, 48.

Ponadto do spodni używano haftek ${ }^{116}$, najprawdopodobniej do zapinania nogawek i wspomnianej przedniej klapy, tak wyraźnie wskazanej na rycinie z Kriegsarchiv w Wiedniu. ${ }^{117}$ Nogawki sukiennych spodni węgierskich zapinano w armii austriackiej na 7 rzędów haftek każdą, a piętnastą parę przeznaczano pod klapkę. ${ }^{118}$ Podszewkę do spodni zarówno szeregowych, jak i podoficerów wykonywano z dwóch arszynów grubego płótna konopnego. ${ }^{119}$ Było to zdecydowanie więcej niż przeznaczano na podszewkę w spodniach austriackich, w których była to jedynie trzecia część łokcia - głównie pod tył i kolana. ${ }^{120}$ Możemy więc wnioskować, iż podszewka w spodniach w chorągwi Rzewuskiego znajdowała się poza stanem na całości materiału.

116 AN w Krakowie, AS, Ap, Podh IV/L, plik 42, Specyfikacya potrzeb należących do monduru wielkiego..., 20 IV 1756 r., b.p.; plik 48, Specyfikacya potrzeb należących do monduru wielkiego..., 12 IV 1760 r., b.p.; Podh IV/XLVII, plik 25, Specyfykacya małego moderunku..., 13 VII 1761 r., b.p.; plik 38, Specyfikacya potrzeb należących małego moderunku..., $1 \mathrm{X}$ 1763 r., b.p.; plik 44, Regestr percepty y expensy..., 27 VII 1764 r., b.p.; plik 71, Specyfikacya potrzeb należących..., 1768 r., b.p.

117 ÖStA/KA, BS L IV, 32, „Allgemeiner Aufriss..., Zwölfter Theil, b.m., [ca. 1769-1773], 33-35, rkps.

118 Ibid.

119 AN w Krakowie, AS, Ap, Podh IV/XLVII, plik 11, Regestr percepty y expensy na drobny moderunek..., 8 IX 1753 r., b.p.; plik 25, Specyfykacya małego moderunku..., 13 VII 1761 r., b.p.; Podh IV/XL, plik 1, Specyfikacja drobnego moderunku..., 29 VII 1755 r., b.p.

120 ÖStA/KA, BS L IV, 32, „Allgemeiner Aufriss...”, Zwölfter Theil, b.m., [ca. 1769-1773], 33-35, rkps. 
Żołnierze nosili „buty węgierskie”. W 1752 r. kosztowały one 4 zł. ${ }^{121}$ W specyfikacji z 1754 r. opisano je jako „Buty czarne, sznurkowane, krojem węgierskim o dwóch podeszwach". ${ }^{122}$ Owa podwójna podeszwa stanowi polski odpowiednik „Doppelsohle" - czyli podpodeszwy. Z kolei w 1755 r. określono je jako but „na obcasach niemiecki”. ${ }^{123}$ Przypuszczać możemy, iż krojem buty te nie zmieniły zasadniczo wyglądu, gdyż wspomniany opis z $1755 \mathrm{r}$. wzmiankował

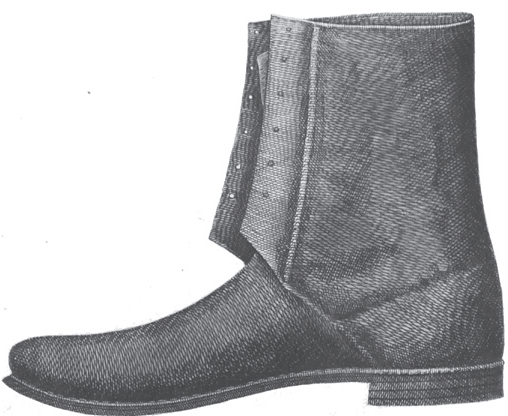

Ryc. 3. Buty węgierskie. Źródło: ÖStA/KA, BS L IV, 32, „Allgemeiner Aufriss..., Zwölfter Theil, fot. J. Hofman m.in. trzy łokcie sznurka włóczkowe-

go w cenie 2 gr za łokieć do „obsznurkowania” cholew tychże butów (rok później sznurek kosztował 1,5 gr $^{124}$ ), co zgadza się $\mathrm{z}$ charakterystyką obuwia zamawianego w 1765 r. - buty te miały być „na abcasach, krojem węgierskim y sznurkowane cholewy". ${ }^{125}$ Buty węgierskie ze względu na kształt (cholewy sięgały za kostkę), były droższe od trzewików noszonych przez żołnierzy Regimentu Pieszego Buławy Polnej Koronnej. Jeden z wariantów takich butów posiadających bardzo wysoko usytuowane kwatery, czyli cholewkę sięgającą nawet $16 \mathrm{~cm}$ od podeszwy, opisane jako „Hungarische art” przedstawiono w „Allgemeiner Aufriss...” z drugiej połowy XVIII w. ${ }^{126}$ Buty takie odpowiadają zarówno opisowi źródłowemu, jak i grafice Raspego. $\mathrm{Na}$ początku lat pięćdziesiątych XVIII w. kosztowały między 4 a 5 zł, następnie ich cena wzrosła do 5,5 (1756), 6 (1760-1764), a później nawet 7,5 zł za sztukę.

\footnotetext{
121 AN w Krakowie, AS, Ap, Podh IV/XLVII, plik 23, Specyfikacya munderunku chorągwi..., 17 VII 1752 r., b.p.

122 Ibid., plik 16, Ogułem [sic!] spisanych rzeczy..., 29 III 1754 r., b.p.

123 Ibid., Podh IV/XL, plik 1, Specyfikacja drobnego moderunku..., 29 VII 1755 r., b.p.

124 Ibid., Podh IV/L, plik 42, Specyfikacya potrzeb należących do monduru wielkiego..., 20 IV 1756 r., b.p.

125 Ibid., Podh III, pudło IV/1, plik 50, Rolla lenugowa chorągwi piechoty węgierskiey buławy polney koronney, Zahorce, luty 1757 r., b.p.; Podh IV/L, plik 42, Specyfikacya potrzeb należących do monduru wielkiego..., 20 IV 1756 r., b.p.; plik 48, Specyfykacya potrzeb należących do monduru wielkiego..., 12 IV 1760 r., b.p.; Podh III, pudło IV/1, plik 48, Specyfikacya butów należących dla ludzi chorągwi piechoty węgierskiey komputowy JW. pana wojewody krakowskiego hetmana polnego koronnego a to die prima februarii ad primam Augusti $1765 \mathrm{a}[\mathrm{nn}] \mathrm{o}$ to iest na puł roku która specyfikacya podaie się panu dobrodziejowi, Podhorce, 7 II 1765 r., b.p.
}

126 ÖStA/KA, BS L IV, 32, „Allgemeiner Aufriss...”, Zwölfter Theil, b.m., [ca. 1769-1773], $49-56,147$, ryc. 10 , rkps. 
Tabela 3. Ceny obuwia w latach $1752-1768$

\begin{tabular}{|c|l|}
\hline Rok & Cena \\
\hline 1752 & $4 \mathrm{zł}$ \\
\hline 16 III 1753 & $4 \mathrm{zł}$ \\
\hline 8 IX 1753 & $4 \mathrm{zł} 25 \mathrm{gr}$ \\
\hline 1754 & $5 \mathrm{zł} 15 \mathrm{gr}$ \\
\hline 1755 & $6 \mathrm{zł}$ \\
\hline 1756 & $5 \mathrm{zł} 15 \mathrm{gr}$ \\
\hline I 1757 & $6 \mathrm{zł}$ \\
\hline II 1757 & $6 \mathrm{zł} 10 \mathrm{gr}^{* *}$ \\
\hline 1758 & $6 \mathrm{zl}^{*}$ \\
\hline 1760 & $6 \mathrm{zł}^{15} \mathrm{gr}^{* *}$ \\
\hline
\end{tabular}

\begin{tabular}{|r|l|}
\hline Rok & Cena \\
\hline 1 II 1760 & $6 \mathrm{zl}$ \\
\hline 12 IV 1760 & $6 \mathrm{zl}$ \\
\hline II 1761 & $7 \mathrm{zł}$ \\
\hline 13 VII 1761 & $8 \mathrm{zl}^{*}\left(^{*}\right)$ \\
\hline 1763 & $6 \mathrm{zl}$ \\
\hline 1764 & $6 \mathrm{zl}$ \\
\hline 1765 & $7 \mathrm{zł} 15 \mathrm{gr}^{* *}$ \\
\hline 1766 & $7 \mathrm{zł}$ \\
\hline 25 I 1768 & $7 \mathrm{zł}$ \\
\hline 1768 & $6 \mathrm{zł} 15 \mathrm{gr}$ \\
\hline
\end{tabular}

ze sznurkiem

** ze sznurkiem i podkuciem

Źródło: oprac. własne autora na podstawie: AN w Krakowie, AS, Ap, Podh IV/XLVII, pliki: 11, 17, 22, 23, 25, 32, 39, 48, 59, 75, 85; Podh IV/XL, pliki: 1, 6, 20; Podh IV/L, pliki: 42, 48; Podh III, pudło IV/1, pliki: 48, 50, 78, 90.

Z innych rachunków wiemy, że buty te wzmacniano „podkówkami”, które przybijali kowale. ${ }^{127}$ Płacono za tę usługę początkowo 6 gr a następnie 8 , 12,13 a nawet 15 gr. $\mathrm{Z}$ innego rachunku z $1764 \mathrm{r}$. wynika, że podkuwano jedynie buty szeregowych, gdyż buty „unterofficerów robią na obcasach”, co oznaczało, iż były one wyższe niż u szeregowych i zużywały się wolniej. ${ }^{128}$

Tabela 4. Koszty podkucia obuwia szeregowych w latach 1753-1764

\begin{tabular}{|c|c|}
\hline Rok & Cena \\
\hline 1753 & $6 \mathrm{gr}$ \\
\hline 1754 & $8 \mathrm{gr}$ \\
\hline 11 II 1756 & $6 \mathrm{gr}$ \\
\hline 20 IV 1756 & $8 \mathrm{gr}$ \\
\hline 1758 & $8 \mathrm{gr}$ \\
\hline 1760 & $8 \mathrm{gr}$ \\
\hline
\end{tabular}

\begin{tabular}{|c|c|}
\hline Rok & Cena \\
\hline 1761 & $10 \mathrm{gr}$ \\
\hline 16 I 1763 & $12 \mathrm{gr}$ \\
\hline 1 X 1763 & $13 \mathrm{gr}$ \\
\hline 28 I 1764 & $15 \mathrm{gr}$ \\
\hline 27 VII 1764 & $13 \mathrm{gr}$ \\
\hline
\end{tabular}

Źródło: oprac. własne autora na podstawie: AN w Krakowie, AS, Ap, Podh IV/XLVII, pliki: 1, 17, 22, 32, 38, 39, 44; Podh IV/XL, pliki: 6, 20; Podh IV/L, pliki: 42, 48; Podh III, pudło IV/1, plik 90.

127 AN w Krakowie, AS, Ap, Podh IV/XLVII, plik 15, [Kwit na odebranie pieniędzy do podszycia i podkucia butów przez Michała Erdellego], b.m., 20 I 1754 r., b.p.; plik 29, Rolla lenugowa chorągwi piechoty węgierskiej komputowey JWjmci pana wojewody podolskiego hetmana polnego koronnego, Zahorce, 1-24 II 1762 r., b.p.; Podh III, pudło VI/1, plik 50, Rolla lenugowa chorągwi..., luty 1757 r., b.p.

128 Ibid., Podh IV/XLVII, plik 39, Specyfikacya butów nowych należących dla ludzi chorągwi piechoty węgierskiey komputowey pana [Wacława] Rzewuskiego wojewody krakowskiego het- 
Posiadamy kilka źródeł, które potwierdzają fakt podszywania butów węgierskich w latach $1754-1755 .{ }^{129}$ Nie wiemy, czy w okresie $1756-1768$ buty nadal podszywano, czy wykonywane już były z „podszyciem”. Ceny podszycia butów kształtowały się jak w tabeli poniżej.

Tabela 5. Koszty podszycia obuwia szeregowych w latach 1753-1755

\begin{tabular}{|c|c|c|c|c|}
\hline Rok & 1753 & 20 I 1754 & 16 III 1754 & 1755 \\
\hline Cena & 2 zł 6 gr & $2 \mathrm{zł}^{\circ} \mathrm{gr}^{*}$ & $3 \mathrm{zł}$ & $2 \mathrm{zł} 18 \mathrm{gr}$ \\
\hline
\end{tabular}

z podkuciem

Źródło: oprac. własne autora na podstawie: AN w Krakowie, AS, Ap, Podh IV/XLVII, pliki: 9, 15; Podh III, pudło IV/1, pliki: 4, 26.

Buty sporządzano lokalnie. W 1754 r. rozważano zamówienie gotowych w Chełmie lub Brodach, w 1763 r. zawarto kontrakt z szewcami podhoreckimi, a w latach $1766-1768$ wykonanie zlecano szewcom w Olesku. ${ }^{130}$

Rolę pendentów u żołnierzy węgierskich pełniły pasy skórzane do szabel. Dodatkowo na żupanikach nosili oni ozdobne pasy włóczkowe "przerabiane" węzłami, w formie pasów noszonych przez formacje huzarskie w Prusach i Austrii w tym samym czasie. ${ }^{131}$ Początkowo podoficerowie mieli nosić pasy „kamelharowe, pąsowe $\mathrm{z}$ węzłami szafirowymi srebrem przerabianymi". ${ }^{132}$ Zrezygnowano jednak ze zdobienia ich srebrem, zastępując

mana polnego koronnego a die prima Februarii ad primam August 1764, która specyfikacya z wyrażeniem osób podaie się panu, Podhorce, 28 I 1764 r., b.p.

129 Ibid., Podh III, pudło IV/1, plik 4, Regestr podszycia butów od chorągwi piechoty węgierskiey buławy polney koronney, Zahorce, 1 I 1753 r., b.p.; plik 26, Regestr podszycia butów dla ludzi chorągwi piechoty węgierskiey buławy polney koronney, Zahorce, 1 I 1755 r., b.p.; plik 48, Rolla lenugowa chorągwi piechoty węgierskiej jaśnie wielmożnego Jmci pana wojewody podolskiego, hetmana polnego koronnego, Zahorce, 1-24 I 1757 r., b.p.; Podh IV/ XLVII, plik 9, [Kwit na odebrane...], 16 V 1754 r., b.p.; plik 15, [Kwit na odebranie pieniędzy...], 20 I 1754 r., b.p.

${ }^{130}$ Ibid., Podh III, pudło IV/1, plik 48, Specyfikacya butów należących..., 7 II 1765 r., b.p.; Podh IV/XLVII, plik 16, Ogułem [sic!] spisanych rzeczy..., 29 III 1754 r., b.p.; plik 39, Specyfikacya butów nowych należących..., 28 I 1764 r., b.p.; plik 75, Specyfikacya należących butów dla ludzi chorągwi piechoty węgierskiey buławy polney koronney, a die 1ma February 1768 ad diem 1mam February Anni ejusdem, Podhorce, 25 I 1768 r., b.p.; plik 85, Expens na mundur wielki..., 22 XI 1768 r., b.p.; Podh IV/L, plik 42, Specyfikacya potrzeb należących do monduru wielkiego..., 20 IV 1756 r., b.p.

131 ÖStA/KA, BS L IV, 32, „Allgemeiner Aufriss..., Erster Theil, b.m., [ca. 1769-1773], 109, ryc. 5, rkps; Daniel Hohrath, The Uniforms of the Prussian Army under Frederick the Great from 1740 to 1786, t. 1-2 (Vienna: Verlag Militaria, 2011), 1:84; 2:619, 665.

132 AN w Krakowie, AS, Ap, Podh IV/XLVII, plik 16, Ogułem [sic!] spisanych rzeczy..., 29 III 1754 r., b.p. 
kruszec jedwabiem. ${ }^{133}$ Szeregowi i muzycy nosili pasy „włóczkowe z węzłami włóczkowymi, szafirowymi". ${ }^{134}$ Pasy podoficerskie kosztowały przynajmniej do $1766 \mathrm{r}$. po $10 \mathrm{zł}$ za sztukę, natomiast wełniane pasy szeregowych rozliczane były wraz z resztą „potrzeb włóczkowych". ${ }^{135}$ Wydaje się, iż poza uroczystym i ozdobnym charakterem pasy włóczkowe nie pełniły żadnej użytkowej roli.

Chorągiew Piechoty Węgierskiej Buławy Polnej Koronnej posiadała etatowo dwóch fajfrów oraz dwóch doboszy. ${ }^{136}$ Podobnie jak $\mathrm{w}$ regimencie pieszym, tak w chorągwi węgierskiej za czasów hetmana wielkiego koronnego Potockiego muzycy posiadali odwrócone kolory - szafirowe suknie wierzchnie podszyte kirem w tym samym kolorze i czerwone żupaniki wraz ze spodniami. Kolory te noszono aż do 1752 r. ${ }^{137}$ Późnie Wacław Rzewuski ujednolicił barwę muzyków

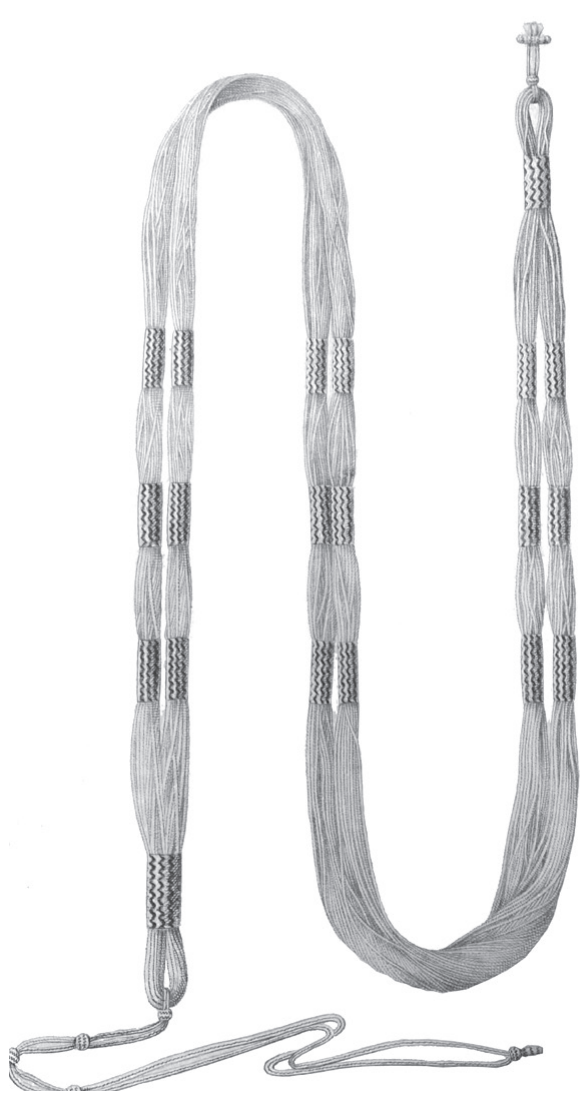

Ryc. 4. Pas włóczkowy. Źródło: ÖStA/KA, BS L IV, 32, „Allgemeiner Aufriss...," Erster Theil, fot. J. Hofman

133 Ibid., plik 17, Rejestr percept y expens..., 11 IV 1754 r., b.p.

134 Ibid., Podh IV/XL, plik 20, Specyfikacya potrzeb do monduru wielkiego..., 24 IV 1758 r., b.p.; Podh IV/XLVII, plik 16, Ogułem [sic!] spisanych rzeczy..., 29 III 1754 r., b.p.

135 Ibid., Podh IV/XLVII, plik 17, Rejestr percept y expens..., 11 IV 1754 r., b.p.; plik 44, Regestr percepty y expensy..., 27 VII 1764 r., b.p.; plik 59, Regestr percepty y expensy..., 13 XII 1766 r., b.p.; plik 85, Expens na mundur wielki..., 22 XI 1768 r., b.p.; Podh IV/L, plik 42, Specyfikacya potrzeb należących do monduru wielkiego..., 20 IV 1756 r., b.p.; plik 48, Specyfykacya potrzeb należących do monduru wielkiego..., 12 IV 1760 r., b.p.; Podh IV/XL, plik 20, Specyfikacya potrzeb do monduru wielkiego..., 24 IV 1758 r., b.p.

136 Zob. aneks nr 2; AN w Krakowie, AS, Ap, Podh III, pudło IV/1, pliki 1-205f, Role lenugowe, $1752-1769$, b.p.

137 AN w Krakowie, AS, Ap, Podh IV/XLVII, plik 23, Specyfikacya munderunku chorągwi..., 17 VII 1752 r., b.p.; Podh III, pudło IX/III, plik 14, Specyfikacya odebranego moderunku..., 7 II 1749 r., b.p.; Podh III, pudło V/1, plik 3, [Specyfikacja] na chorągwie regimentu pieszego..., 14 II 1749 r., b.p. 
i szeregowych, a jedynym widocznym wyróżnieniem pozostały dodatkowe borty „doboskie”, czyli wełniana ozdobna pasmanteria $\mathrm{w}$ formie tkanej lub plecionej taśmy. Naszywano je najprawdopodobniej jedynie na rękawy katanek wierzchnich. Ich ilość uległa także ograniczeniu. W specyfikacji na 1752 r. przewidziano 67 łokci taśmy dla czterech muzyków, a w specyfikacjach z okresu $1754-1764$ już tylko po 10 łokci na osobę. ${ }^{138}$ W 1766 r. zamówiono jej już 46 łokci, jednak w niższej cenie, po 12 gr, podczas gdy wcześniej, do 1764 r., płacono za nią po 20 gr. ${ }^{139} \mathrm{~W}$ opisywanym okresie przez szeregi muzyków przewinęło się co najmniej 6 fajfrów i 12 doboszy. Niektórzy służyli bardzo krótko po zaledwie 1-3 miesiące (np. Józef Niedzielski, Franciszek Jankowski, Jan Meron - dwukrotnie), inni po okresie służby muzycznej stawali się szeregowymi (m.in. Piotr Buczko, Sebastian Wierzbicki, Maciej Balicki po 1769 r., Wojciech Bisiur, Jan Kopczyński) lub odwrotnie - porzucali karabin na rzecz piszczałki (Ignacy Dzwoniecki, Marcin Kopczyński, Mikołaj Lewandowski), bądź bębna (Balicki po czerwcu 1763 r., Józef Majewski, Meron, Mosakiel po grudniu 1760 r.). Niektórzy (Stanisław Mosakiel, Antoni Wierzbicki) bębnili dorywczo, co raczej było konsekwencją braków kadrowych niż chęci zmiany funkcji żołnierskiej. Jak wynika $\mathrm{z}$ analizy zestawienia osobowego muzyków, średni okres służby wynosił 1 rok i 9 miesięcy. Prawie dwukrotnie wyższy był średni czas służby fajfrów. ${ }^{140}$ Przy tak dużej rotacji można zastanawiać się nad faktycznym wykorzystaniem bort jako elementu zdobniczego munduru doboszy. Niestety brak materiału źródłowego nie pozwala odpowiedzieć na to pytanie.

Jak już zostało wspomniane, mundur podoficerów różnił się od munduru szeregowych zastosowaniem srebrzonych sznurków i tasiemek oraz lepszym jakościowo suknem. Analiza zachowanych specyfikacji wskazuje, że po przejęciu dowództwa nad chorągwią przez Rzewuskiego zmienił się nieco sposób dystyngowania podoficerów. Wcześniej każdy z nich otrzymywał po 8 łokci srebrnego galonu, kosztującego po 3 zł za łokieć. ${ }^{141}$ Później próbowano wprowadzić rozróżnienie między wachmistrzem i podchorążym a felczerem i kapralami. Ci pierwsi mieli otrzymać 12 łokci „galonu srebrnego gładkiego, pojedynkowego, na półtora cala szerokiego" do katanek

138 Ibid., Podh IV/XLVII, plik 17, Rejestr percept y expens..., 11 IV 1754 r., b.p.; plik 44, Regestr percepty y expensy..., 27 VII 1764 r., b.p.; Podh IV/L, plik 42, Specyfikacya potrzeb należących do monduru wielkiego..., 20 IV 1756 r., b.p.; plik 48, Specyfykacya potrzeb należących do monduru wielkiego..., 12 IV 1760 r., b.p.; Podh IV/XL, plik 20, Specyfikacya potrzeb do monduru wielkiego..., 24 IV 1758 r., b.p.

139 Ibid., Podh IV/XLVII, plik 59, Regestr percepty y expensy..., 13 XII 1766 r., b.p.

140 Zob. aneks nr 2.

${ }^{141}$ AN w Krakowie, AS, Ap, Podh IV/XLVII, plik 23, Specyfikacya munderunku chorągwi..., 17 VII 1752 r., b.p. 
wierzchnich i spodni, pozostali zaś po 9 łokci takiego samego galonu. Dodatkowo każdy miał otrzymać 2,5 łokcia galonu "na ieden palec szerokiego” do oblamowania kapuz. ${ }^{142}$ Zdaje się jednak, że nie wprowadzono tych rozwiązań w życie, gdyż w kwietniu 1754 r. zapotrzebowano jedynie 46 łokci galonu szerokiego do szamerowania sześciu mundurów podoficerskich i po 20 łokci galonu wąskiego do kapuz i na cyfry na nich wyszywane. ${ }^{143}$ Dokładne prześledzenie zmian w ilości galonów jest niezwykle trudne, gdyż często określa się je tymi samymi nazwami i w efekcie nie bardzo wiemy, czy mamy do czynienia $\mathrm{z}$ galonem przeznaczonym na mundur czy/lub/i na kapuzę. Dodatkowo w źródłach pojawia się tajemniczy zapis o kutasikach srebrnych dodawanych do fałd sukien wierzchnich. ${ }^{144}$ Do szamerowania używano „sznurków srebrem powlekanych” w ilości 385 łokci. ${ }^{145}$

W 1766 r. rozróżnienie na galon szeroki i wąski już nie występowało, a podoficerowie otrzymali 80 łokci "galonu srebrnego pojedynczego" na mundur i do oblamowania kapuz, jednocześnie do szamerowania guzików szmuklerz miał sporządzić 372 łokcie (po 62 łokci na osobę) „sznurku srebrem powlekanych". ${ }^{146}$ Koszt uszycia munduru podoficerskiego wraz z płaszczem wynosił $5 \mathrm{zt}^{147}$, od 1758 r. $6 \mathrm{zt}^{148}$, a następnie od 1762 r. $6,5 \mathrm{zl}^{149}$

Jednym z wyróżników munduru podoficerskiego były płaszcze sporządzane $\mathrm{w}$ ramach wielkiego munduru. Wykonywano je $\mathrm{z}$ ordynaryjnego sukna czerwonego i podszywano częściowo szafirowym kirem. W 1752 r. na płaszcze przeznaczano 6 łokci sukna i 1,25 kiru, a od 1754 r. już 8 łokci sukna i 2 łokcie kiru. ${ }^{150}$

142 Ibid., plik 13, Specyfikacja rekwizytów..., 29 III 1754 r., b.p.
143 Ibid., plik 17, Rejestr percept y expens..., 11 IV 1754 r., b.p.
144 Ibid., plik 44, Regestr percepty y expensy..., 27 VII 1764 r., b.p.; plik 59, Regestr percepty y expensy..., 13 XII 1766 r., b.p.

145 Ibid., Podh IV/XL, plik 20, Specyfikacya potrzeb do monduru wielkiego..., 24 IV 1758 r., b.p.; Podh IV/L, plik 48, Specyfykacya potrzeb należących do monduru wielkiego..., 12 IV 1760 r., b.p.

146 Ibid., Podh IV/XLVII, plik 59, Regestr percepty y expensy..., 13 XII 1766 r., b.p.

147 Ibid., Podh IV/L, plik 42, Specyfikacya potrzeb należących do monduru wielkiego..., 20 IV 1756 r., b.p.; Podh IV/XLVII, plik 1, Specyfikacya wiele ieszcze potrzeba..., 16 IX 1754 r., b.p.; plik 13, Specyfikacja rekwizytów..., 29 III 1754 r., b.p.; plik 17, Rejestr percept y expens..., 11 IV 1754 r., b.p.

148 Ibid., Podh IV/XL, plik 20, Specyfikacya potrzeb do monduru wielkiego..., 24 IV 1758 r., b.p.; Podh IV/L, plik 48, Specyfykacya potrzeb należących do monduru wielkiego..., 12 IV 1760 r., b.p.

149 Ibid., Podh II 131, Specyfikacya rekwizytów dla..., 21 IV 1762 r., 49; Podh IV/XLVII, plik 44, Regestr percepty y expensy..., 27 VII 1764 r., b.p.; Podh IV/XLVII, plik 59, Regestr percepty y expensy..., 13 XII 1766 r., b.p.

150 Ibid., Podh IV/XLVII, plik 13, Specyfikacja rekwizytów..., 29 III 1754 r., b.p.; plik 23, Specyfikacya munderunku chorągwi..., 17 VII 1752 r., b.p. 
Późniejsze rachunki milczą na temat zakupu tkaniny podszewki, a ilość sukna „trzydziestkowego" - ordynaryjnego - zmniejsza się od 1763 r. z 8 do 7,5 lokcia. ${ }^{151} \mathrm{~W}$ specyfikacji tkanin na zakup wielkiego munduru $\mathrm{z}$ grudnia $1766 \mathrm{r}$. na płaszcze dla podoficerów przeznaczono już tylko 44 łokcie sukna czerwonego, nie wymieniano natomiast ilości kiru. ${ }^{152}$ Zapewne wraz z reformą płacy w 1767 r. do kompanii wprowadzono abcugi, czyli potrącenia (z niem. Abzug) na zakup płaszczów dla szyldwachów, czyli żołnierzy pełniących służbę wartowniczą pod bronią. Były one już niemal w całości podszywane kuczbojem $^{153}$ (7 łokci) i wyposażone w guziki. ${ }^{154}$

Drugim z wyróżników munduru podoficerskiego były jedwabne portepee (chwosty) mocowane przy rękojeściach szabel. W źródłach pojawiają się w 1758 r. Ich cena wynosiła 3 zł. ${ }^{155}$ Otrzymywali je wszyscy podoficerowie z wyjątkiem felczera. Ponadto w 1768 r. podoficerowie (z wyjątkiem felczera) otrzymali skórzane rękawiczki. ${ }^{156}$

Niezwykle ważnym elementem ledewerku ${ }^{157}$ pozostawały tarszule (taszule), czyli ozdobne, skórzane torby (dosłownie kaletki, kalitki) przypięte rzemieniami do pasa od szabli, wywodzące się z węgierskiego Tarsoly. Obecnie w języku polskim używa się zniemczonej i bardziej spopularyzowanej nazwy szabeltasu (z niem. Säbeltasche). ${ }^{158}$ Jego kształt przypominał huzarskie szabeltasy noszone w tym czasie w innych armiach europejskich. ${ }^{159}$ Przód przybierał bogatą formę. Obszyty był szafirowym suknem, na którym

151 Ibid., Podh IV/L, plik 47, Specyfikacya rekwizytów dla chorągwi węgierskiey JW. JM pana woiewody podolskiego hetmana polnego kor[onnego] pro 1ma Augusti 1760 a[nn]o do barwy należących, które z Les[z]na wyprowadzone będą, Podhorce, 12 IV 1760 r., b.p.; Podh II 131, Specyfikacya rekwizytów dla..., 21 IV 1762 r., 49; Podh IV/XLVII, plik 44, Regestr percepty y expensy..., 27 VII 1764 r., b.p.

152 Ibid., Podh IV/XLVII, plik 59, Regestr percepty y expensy..., 13 XII 1766 r., b.p.

153 Rodzaj tkaniny wełnianej o splocie płóciennym.

154 AN w Krakowie, AS, Ap, Podh IV/XLVII, plik 85, Expens na mundur wielki..., 22 XI 1768 r., b.p.

155 Ibid., Podh IV/XL, plik 20, Specyfikacya potrzeb do monduru wielkiego..., 24 IV 1758 r., b.p.; Podh IV/XLVII, plik 44, Regestr percepty y expensy..., 27 VII 1764 r., b.p.; plik 59, Regestr percepty y expensy..., 13 XII 1766 r., b.p.; Podh IV/L, plik 48, Specyfykacya potrzeb należących do monduru wielkiego..., 12 IV 1760 r., b.p.

156 Ibid., Podh IV/XLVII, plik 85, Expens na mundur wielki..., 22 XI 1768 r., b.p.

157 Ledewerk, od niem. das Leder - wyprawiona skóra i das Werk - dzieło; czyli wyposażenie żołnierskie wykonane ze skóry.

158 Amtsblatt zur Lemberger Zeitung. Dziennik urzędowy do Gazety Lwowskiej, nr 251, listopad 4, 1853, 1840.

159 ÖStA/KA, BS L IV, 32, „Allgemeiner Aufriss..., Dritten Theils, Erster Abschnitt, b.m., [ca. 1768-1773], 91-92 wraz z rycinami, rkps; Raspe, Accurate, tab. 47 i 48; Hohrath, The Uniforms, 1:104-105; 2:484, 530, 538-539, 555, 658-659; Constantin Kling, Allgemeine Geschichte der Bekleidung und Ausrüstung des altpreussischen Heeres, Dritte theil: Die Kürrasier 
naszywano herb Korony - Białego Orła na czerwonym tle. W 1752 r. na 67 tarszul zużyto 18 łokci sukna szafirowego, dwa lata później na 70 tarszul zapotrzebowano już 24 łokcie tegoż sukna. Natomiast na herby w $1752 \mathrm{r}$. zamówiono 6 łokci sukna czerwonego i 4 białego. ${ }^{160} \mathrm{~W} 1756$ r. na 70 tarszul wzięto 14 łokci sukna szafirowego, 3 łokcie czerwonego i 4 białego. ${ }^{161}$ Taką ilość sukna białego zamówiono też w 1764 i 1766 r. ${ }^{162}$ Zmiany ilości zapotrzebowanych materiałów najprawdopodobniej wynikały ze zmniejszenia rozmiarów kaletki. Koszt jej wykonania przez rymarza, wraz z wyszyciem herbu przez rzemieślnika Matysa Namiotnika (Namiestnika/Namietnika), wynosił w 1752 r. 3 zł i ok. 4 zł w latach $1753-1766 .{ }^{163}$

Niewiele wiemy na temat ładownic noszonych przez „Węgrów”. Chorągiew w chwili przenoszenia się do Podhorzec miała 59 starych ładownic, które miano oddać Namiotnikowi do „wyszywania herbów”. Brakujących osiem ładownic sporządził rymarz. ${ }^{164}$ Kolejne trzy sporządził już białoskórnik brodzki w 1753 r. ${ }^{165}$ Ładownice te wraz z pasami nośnymi regularnie naprawiano. W 1754, 1756 i 1758 r. na naprawę ładownic i pasów do szabel przeznaczono po 1 tynfie (38-39 gr) na żołnierza. ${ }^{166} \mathrm{~W} 1760$ r. zakupiono

und Dragoner-Regimenter seit anfangs des 18 Jahrhunderts bis 1808 (Weimar: Buch und Steindruckerei von Putze \& Hölzer, 1906), 84-85.

160 AN w Krakowie, AS, Ap, Podh IV/L, plik 42, Specyfikacya potrzeb należących do monduru wielkiego..., 20 IV 1756 r., b.p.; Podh IV/XLVII, plik 17, Rejestr percept y expens..., 11 IV 1754 r., b.p.; plik 23, Specyfikacya munderunku chorągwi..., 17 VII 1752 r., b.p.; plik 44, Regestr percepty y expensy..., 27 VII 1764 r., b.p.

161 Ibid., Podh IV/L, plik 42, Specyfikacya potrzeb należących do monduru wielkiego..., 20 IV 1756 r., b.p.

162 Ibid., Podh IV/XLVII, plik 59, Regestr percepty y expensy..., 13 XII 1766 r., b.p.; w 1760 i 1761 r. zamówiono 6 łokci sukna białego na herby do tarszul; Podh IV/XLVII, plik 25, Specyfykacya małego moderunku..., 13 VII 1761 r., b.p.; Podh IV/L, plik 48, Specyfykacya potrzeb należących do monduru wielkiego..., 12 IV 1760 r., b.p.

163 Ibid., Podh IV/XLVII, plik 17, Rejestr percept y expens..., 11 IV 1754 r., b.p.; plik 22, Regestr sprawienia barw na gemeinów..., 16 III 1753 r., b.p.; plik 23, Specyfikacya munderunku chorągwi..., 17 VII 1752 r., b.p.; plik 59, Regestr percepty y expensy..., 13 XII 1766 r., b.p.; plik 85, Expens na mundur wielki..., 22 XI 1768 r., b.p.; Podh IV/L, plik 42, Specyfikacya potrzeb należących do monduru wielkiego..., 20 IV 1756 r., b.p.; plik 48, Specyfykacya potrzeb należących do monduru wielkiego..., 12 IV 1760 r., b.p.; Podh IV/XL, plik 20, Specyfikacya potrzeb do monduru wielkiego..., 24 IV 1758 r., b.p.; w 1760 r. 3 zabrane przez dezerterów taszule i kaletki wyceniono na 4 zł i 18 gr (Podh IV/L, plik 46, Specyfikacya decessu w mondurze..., 30 XI 1760 r., b.p.), a w 1764 r. na 4 zł i 3 gr (Podh IV/XLVII, plik 44, Regestr percepty y expensy..., 27 VII 1764 r., b.p.).

164 Ibid., Podh IV/XLVII, plik 23, Specyfikacya munderunku chorągwi..., 17 VII 1752 r., b.p.

165 Ibid., plik 22, Regestr sprawienia barw na gemeinów..., 16 III 1753 r., b.p.

166 Ibid., Podh IV/L, plik 42, Specyfikacya potrzeb należących do monduru wielkiego..., 20 IV 1756 r., b.p.; Podh IV/XLVII, plik 17, Rejestr percept y expens..., 11 IV 1754 r., b.p.; Podh IV/XL, plik 20, Specyfikacya potrzeb do monduru wielkiego..., 24 IV 1758 r., b.p. 
dla wszystkich żołnierzy nowy ledewerk, tj. „paski do szabel i ładownice z blachami mosiężnymi herbowymi", którego cenę ustalono na 12 zł. ${ }^{167} \mathrm{Zda}-$ je się, iż do samego 1768 r. nie przeprowadzono kolejnej wymiany ledewerku na nowy, a jedynie okazjonalnie uzupełniano brakujące wyposażenie o utracone sztuki; w 1764 r. ładownica z paskami do szabli kosztowała $12 \mathrm{zl}$, a w 1766 r. 11 zł. ${ }^{168} \mathrm{O}$ blachach na ładownice dla podoficerów i gemeinów sporządzonych przez złotnika brodzkiego za 50 gr sztuka wspomina się także w 1768 r. ${ }^{169}$

Opisane już wcześniej pasy włóczkowe nie nadawały się do noszenia broni bocznej. W związku z tym wyposażenie żołnierskie uzupełniały skórzane pasy $\mathrm{z}$ rapciami do noszenia szabel $\mathrm{i}$ tarszul. Po zmianie szefa $\mathrm{w}$ chorągwi brakowało do kompletu 8 pasków do szabel. ${ }^{170}$ Paski te prawdopodobnie wykonane były ze skóry laszowanej, czyli wyprawianej przy zastosowaniu ałunu przez białoskórnika, zwanego inaczej leszownikiem. ${ }^{171} \mathrm{~W} 1753 \mathrm{r}$. wykonanie pasów do szabel wraz z tarszulami i ładownicami zlecono białoskórnikowi z Brodów ${ }^{172}$, a w dwóch rachunkach z 1754 i 1761 r. wspomina się o "pasach łosiowych” lub „łosich”. Kosztowały one odpowiednio 5 oraz 8 zł. Te ostatnie wykonano ze „[s] przączkami, wypustkami i szleftkami mosiężnymi”. ${ }^{173} \mathrm{~W} 1760 \mathrm{r}$. zabrane przez dezerterów trzy paski do szabel wyceniono na 6 zł sztuka. ${ }^{174}$ Trzy lata później sporządzono do kompletu 7 sztuk po 4 zł każda, a w 1766 r. za paski do „samych szabel na osób 4" dano 20 zł. ${ }^{175}$

Podobnie jak w piechocie autoramentu cudzoziemskiego żołnierze powinni posiadać rencle (ręcle), czyli torby wykonane ze skórek „cielęcych z paskami rzemiennymi”, zwane w tym czasie, również z języka

167 Ibid., Podh IV/L, plik 48, Specyfykacya potrzeb należących do monduru wielkiego..., 12 IV 1760 r., b.p.

168 Ibid., Podh IV/XLVII, plik 44, Regestr percepty y expensy..., 27 VII 1764 r., b.p.; plik 59, Regestr percepty y expensy..., 13 XII 1766 r., b.p.; plik 85, Expens na mundur wielki..., 22 XI 1768 r., b.p.

169 Ibid., plik 85, Expens na mundur wielki..., 22 XI 1768 r., b.p.

170 Ibid., plik 23, Specyfikacya munderunku chorągwi..., 17 VII 1752 r., b.p.

171 Michał Arct, Słownik staropolski (Warszawa: Wyd. M. Arcta, ca 1920), 175; Słownik języka polskiego, red. Jan Karłowicz, Adam Kryński i Władysław Niedzwiedzki, t. 2, H-M (Warszawa: Kasa im. Mianowskiego, 1902), 721.

172 AN w Krakowie, AS, Ap, Podh IV/XLVII, plik 22, Regestr sprawienia barw na gemeinów..., 16 III 1753 r., b.p.

173 Ibid., plik 17, Rejestr percept y expens..., 11 IV 1754, b.p.; plik 25, Specyfykacya małego moderunku..., 13 VII 1761 r., b.p.; plik 38, Specyfikacya potrzeb należących małego moderunku..., 1 X 1763 r., b.p.

174 Ibid., Podh IV/L, plik 46, Specyfikacya decessu w mondurze..., 30 XI 1760 r., b.p.

175 Ibid., Podh IV/XLVII, plik 38, Specyfikacya potrzeb należących małego moderunku..., 1 X 1763 r., b.p.; plik 59, Regestr percepty y expensy..., 13 XII 1766 r., b.p. 
niemieckiego, tornistrami. Posiadamy niewiele informacji na ich temat. W okresie między 1753 a 1768 r. cena pojedynczego rencla z paskiem wynosiła 2 zł i 18 gr (2 tynfy). ${ }^{176}$ Wykonywano je sporadycznie i - jak wskazuje na to zachowana dokumentacja - nie wszyscy żołnierze je posiadali. W 1753 r. sporządzono 4 szt., w 1755 r. dezerterzy zabrali ze sobą 2 szt., a w 1761 r. już 6 szt. ${ }^{177}$ W 1756 r. zrobiono 15 nowych tornistrów, w $1760 \mathrm{r}$. kolejnych 10 , a trzy lata później $15 .{ }^{178}$ Całkowita wymiana rencli na nowe nastąpiła w 1766 r., co jednak nie pomogło w utrzymaniu ich stanu, gdyż w 1768 r. zamówiono dalszych 12 szt. u rymarza z Oleska. ${ }^{179}$

„Węgrzy” Buławy Polnej uzbrojeni byli podobnie jak piechota autoramentu cudzoziemskiego w karabiny skałkowe oraz broń białą. Według stanu z $1752 \mathrm{r}$. żołnierze użytkowali starą broń: 59 flint w żelaznym garniturze z drewnianymi stemplami oraz 5 karabinów w mosiężnej oprawie, również z drewnianymi stemplami, jedynie $22 \mathrm{z}$ nich posiadało bagnety. Broń ta musiała być dość „skołatana” (zużyta), skoro w 1753 r. za jej naprawę zapłacono ślusarzowi 40 zł, a rok później już 80 zł. ${ }^{180}$ Brakujące do kompletu 7 szt. zamierzano sprowadzić $\mathrm{z}$ Podhorzec. ${ }^{181}$ Wymianę flint na nowe przeprowadzono w 1754 r., a znajdująca się wówczas w Warszawie chorągiew otrzymała 71 nowych karabinów skałkowych „w mosiądz osadzonych”, z „żelaznymi ladsztokami” oraz „trzy graniastymi” bagnetami, grajcarami do wyciągania niewypałów z lufy oraz formę żelazną do odlewania kul. Karabiny te miały mieć mosiężny garnitur okuć, czyli takżą kontrblachę, bączki pod pobojczyk, mindunek, cel, okucie kolby, żelazny pobojczyk oraz bagnet z popularnym w tym czasie przekrojem w kształcie trójkąta równoramiennego. Broń palną otrzymali wachmistrz, podchorąży, 3 kaprali oraz 60 gemajnów. Pozostała broń miała stanowić rezerwę na wypadek uszkodzeń. Przy tej okazji sporządzono tak-

176 Ibid., Podh IV/XL, plik 1, Specyfikacja drobnego moderunku..., 29 VII 1755 r., b.p.; plik 20, Specyfikacya potrzeb do monduru wielkiego..., 24 IV 1758 r., b.p.; Podh IV/XLVII, plik 22, Regestr sprawienia barw na gemeinów..., 16 III 1753 r., b.p.; plik 38, Specyfikacya potrzeb należących małego moderunku..., 1 X 1763 r., b.p.; plik 59, Regestr percepty y expensy..., 13 XII 1766 r., b.p.; Podh IV/L, plik 42, Specyfikacya potrzeb należących do monduru wielkiego..., 20 IV 1756 r., b.p.; plik 48, Specyfykacya potrzeb należących do monduru wielkiego..., 12 IV 1760 r., b.p.

177 Ibid., Podh IV/XL, plik 1, Specyfikacja drobnego moderunku..., 29 VII 1755 r., b.p.; Podh IV/XLVII, plik 25, Specyfykacya małego moderunku..., 13 VII 1761 r., b.p.

178 Ibid., Podh IV/L, plik 42, Specyfikacya potrzeb należących do monduru wielkiego..., 20 IV 1756 r., b.p.; plik 48, Specyfykacya potrzeb należących do monduru wielkiego..., 12 IV 1760 r., b.p.; Podh IV/XLVII, plik 38, Specyfikacya potrzeb należących małego moderunku..., 1 X 1763 r., b.p.

179 Ibid., Podh IV/XLVII, plik 85, Expens na mundur wielki..., 22 XI 1768 r., b.p.

180 Ibid., plik 17, Rejestr percept y expens..., 11 IV 1754 r., b.p.; plik 22, Regestr sprawienia barw na gemeinów..., 16 III 1753 r., b.p.

181 Ibid., plik 23, Specyfikacya munderunku chorągwi..., 17 VII 1752 r., b.p. 
że 65 flintpasów z pojedynczą sprzączką, za które zapłacono po 1 tynfie od sztuki. ${ }^{182}$ Starą broń odesłano do Chełma. ${ }^{183}$

Nowe karabiny psuły się nieco rzadziej. W 1756 r. dokonano wymiany łoża w 3 flintach, które połamano podczas ćwiczeń. Koszt nowej osady wyniósł 10 zł. ${ }^{184}$ Kolejne informacje o dokonywanych przy broni palnej naprawach pochodzą z 1764 r., gdy ślusarz zahorecki osadził 5 flint za sumę 60 zł, a przy pozostałych 57 karabinach dokonał reperacji za łączną kwotę 98 zł i 20 gr. ${ }^{185}$ Kolejnych bliżej nieokreślonych napraw dokonał w $1768 \mathrm{r}$. ślusarz Jan z Podhorzec za kwotę 68 zł. Przy tej okazji osadził w nowych łożach 8 karabinów oraz sporządził 56 brakujących grajcarów. W tym samym czasie miecznik z Brodów sporządził 2 bagnety oraz kilka pochew do nich. ${ }^{186}$ Te ostatnie chętnie zabierali ze sobą dezerterzy. W 1760 r. sporządzenie 2 nowych bagnetów zabranych przez dezerterów wyceniono na $18 \mathrm{zl}$, a w 1763 r. jeden kosztował jedynie 8 zł. ${ }^{187}$

Flintpasy do broni palnej były „rzemienne, szerokie”, ze sprzączkami. Sporządzono ich w 1763 r. 30 szt., a w 1764 r. dalszych 45, odpowiednio po tynfie i złotym. ${ }^{188}$

Chorągiew regularnie zaopatrywano w skałki, papier i proch na ładunki oraz ołów. Poniższa tabela przedstawia fluktuację cen w okresie 1753-1768. Poza wyjątkowym rokiem 1761, w którym zauważyć można zwyżkę cen wszystkich produktów w związku z fałszowaniem monety przez Fryderyka II i spadkiem jej wartości, widzimy dość stabilną cenę papieru. Duża różnica w cenach prochu wynikać może z jego jakości. Z kolei w okresie trwania wojny siedmioletniej obserwujemy stopniowy wzrost cen prochu. Niemal stała pozostała cena skałek, za które płacono po 3 gr. Łącznie od $1763 \mathrm{r}$. do wybuchu walk związanych z konfederacją barską zakupiono co najmniej 660 szt. takowych. W 1753 r. sporządzono po 20 ładunków na każdego z 60 żołnierzy, w sumie 1200 patronów. Pozyskano wówczas 2 kamienie ${ }^{189}$

\footnotetext{
182 Ibid., plik 13, Specyfikacja rekwizytów..., 29 III 1754 r., b.p.; plik 17, Rejestr percept y expens..., 11 IV 1754 r., b.p.

183 Ibid., plik 17, Rejestr percept y expens..., 11 IV 1754 r., b.p.

184 Ibid., Podh IV/L, plik 42, Specyfikacya potrzeb należących do monduru wielkiego..., 20 IV 1756 r., b.p.

185 Ibid., Podh IV/XLVII, plik 44, Regestr percepty y expensy.., 27 VII 1764 r., b.p.

186 Ibid., plik 85, Expens na mundur wielki..., 22 XI 1768 r., b.p.

187 Ibid., Podh IV/L, plik 46, Specyfikacya decessu w mondurze..., 30 XI 1760 r., b.p.; Podh IV/XLVII, plik 38, Specyfikacya potrzeb należących małego moderunku..., 1 X 1763 r., b.p.

188 Ibid., Podh IV/XLVII, plik 38, Specyfikacya potrzeb należących małego moderunku..., 1 X 1763 r., b.p.; plik 44, Regestr percepty y expensy..., 27 VII 1764 r., b.p.

189 Bez większej ilości danych nie jesteśmy w stanie ustalić, o jakiej masie mowa, gdyż w tamtym czasie występowały kamienie o różnych wagach, przykładowo kamień krakowski
} 
prochu i 30 funtów ołowiu oraz 3 libry papieru (60 ryz). ${ }^{190}$ Oznaczało to, iż zarówno waga kuli, jak i prochu wynosiła ok. $21,5 \mathrm{~g}$, a z 1 libry papieru sporządzano 16 tulejek na ładunki. Ołów - 20 funtów - zakupiono jeszcze w 1764 r. razem z kamieniem "prochu przerskiego” i 10 librami papieru oraz w 1768 r. - 25 funtów. ${ }^{191}$ Poza tym jak pokazują zachowane rachunki regularnie zaopatrywano się w proch. Dla okresu od 1753 r. do 1769 r. posiadamy poświadczony zakup 15 funtów.

Tabela 6. Ceny i ilości materiałów zakupionych do produkcji amunicji w latach 1753-1768

\begin{tabular}{|l|c|c|c|c|c|c|c|c|c|c|}
\hline \multicolumn{1}{|c|}{ Rok } & 1753 & 1754 & 1755 & 1756 & 1758 & 1760 & 1761 & 1763 & 1766 & 1768 \\
\hline $\begin{array}{l}\text { Kamień prochu } \\
\text { za funt }\end{array}$ & $\begin{array}{l}41 \mathrm{zł} \\
18 \mathrm{gr}\end{array}$ & $32 \mathrm{zł}$ & & $30 \mathrm{zł}$ & $30 \mathrm{zł}$ & $36 \mathrm{zł}$ & $39 \mathrm{zł}$ & $35 \mathrm{zl}$ & $36 \mathrm{zł}$ & $40 \mathrm{zł}$ \\
\hline Ilość kamieni & 2 & 1 & & 2 & 2 & 2 & 1 & 1 & 2 & 2 \\
\hline Libra papieru & $16 \mathrm{gr}$ & & & & $13 \mathrm{gr}$ & $19,5 \mathrm{gr}$ & $19 \mathrm{gr}$ & $18 \mathrm{gr}$ & $15 \mathrm{gr}$ & $15 \mathrm{gr}$ \\
\hline Liczba libr & 3 & & & & 10 & 10 & 8 & 10 & 10 & 12 \\
\hline Skałki za szt. & $3 \mathrm{gr}$ & & $3 \mathrm{gr}$ & $3 \mathrm{gr}$ & $3 \mathrm{gr}$ & $3 \mathrm{gr}$ & $3,4 \mathrm{gr}$ & $3 \mathrm{gr}$ & $3 \mathrm{gr}$ & \\
\hline Ilość sztuk & 60 & & 60 & 60 & 120 & 120 & 60 & 120 & 60 & \\
\hline Ołowiu za funt & $13 \mathrm{gr}$ & & & & & & & $15 \mathrm{gr}$ & & $30 \mathrm{gr}$ \\
\hline Ilość & 30 & & & & & & & 20 & & 25 \\
\hline
\end{tabular}

Źródło: oprac. własne autora na podstawie: AN w Krakowie, AS, Ap, Podh IV/XLVII, pliki: 17, 22, 25, 38, 59, 85; Podh IV/XL, pliki: 1, 20; Podh IV/L, pliki: 42, 48.

Broń boczną chorągwi stanowiły tradycyjne węgierskie szable. Do kompletu 67 szt. w 1752 r. brakowało 8 szabel, które zamierzano sporządzić w połowie marca 1753 r. Koszt jednej oceniono na 8-9 zł. ${ }^{192}$ Broń ta nie była pierwszej jakości, gdyż w 1754 r. przewidziano na jej reperację fundusz 350 zł, a ponadto 36 zł za wymianę 12 głowni. ${ }^{193}$ Naprawy przeprowadzano w miarę możliwości. We wrześniu $1754 \mathrm{r}$. zapłacono w Chełmie za naprawę szabel 26 zł. ${ }^{194}$ Wkrótce też dokonano wymiany całości. W 1756 r.

miał 26 funtów, warszawski 25, lwowski 36, gdański mały 24, a duży 36, zob. Wojciech Bystrzonowski, Informacya matematyczna rozumnie ciekawego Polaka (Lublin: Societatis JESU, 1743), b.p.

190 AN w Krakowie, AS, Ap, Podh IV/XLVII, plik 22, Regestr sprawienia barw na gemeinów..., 16 III 1753 r., b.p.; funt w zależności od okresu i regionu wynosił między 405 a 500 gram.

191 Ibid., plik 38, Specyfikacya potrzeb należących małego moderunku..., 1 X 1763 r., b.p.

192 Ibid., plik 22, Regestr sprawienia barw na gemeinów..., 16 III 1753 r., b.p.; plik 23, Specyfikacya munderunku chorągwi..., 17 VII 1752 r., b.p.

193 Ibid., plik 17, Rejestr percept y expens..., 11 IV 1754 r., b.p.

194 Ibid., plik 1, Specyfikacya wiele ieszcze potrzeba..., 16 IX 1754 r., b.p. 
w Staszowie zakontraktowano wykonanie 76 szabel w „okowie węgierskim” (6 dla podoficerów, 4 dla muzyków, 60 dla gemeinów i 6 zapasowych), na które rotmistrz Franciszek Bałła odebrał 2 kwietnia 1756 r. z kasy hetmańskiej 926 zł. ${ }^{195}$ Kilka lat później (1761 r.) miecznik brodzki za 6 nowych szabel otrzymał 14 tynfów, a za reperację dalszych 7-8 tynfów. ${ }^{196}$ Kolejne naprawy szabel przewidziano w 1764, 1766 r. oraz 1768 r. ${ }^{197}$ Sporą część budżetu kompanii przeznaczano na zakup nowych, którymi uzupełniano straty spowodowane przez dezerterów. Przykładowo w 1760 r. trzech dezerterów zabrało ze sobą "pałasze z okowem węgierskim”, których koszt wyniósł 12 zł, w 1763 r. trzeba było zdobyć dalszych 7 szt. po 14 zł każda, a w 1764 r. kolejnych 6 po 16 zł. $^{198}$

Podobnie wyglądała sytuacja co do instrumentów muzycznych znajdujących się na wyposażeniu chorągwi. W 1752 r. do kompletu brakowało 1 piszczałki dla fajfra, w miejsce której planowano zakupić 6 nowych z futerałami, natomiast bębnów miano używać starych po ich uprzednim przemalowaniu. ${ }^{199} \mathrm{Na}$ początku 1753 r. przemalowano obręcze zabrane ze skarbu hetmańskiego do jednego z bębnów mosiężnych, który uległ uszkodzeniu. ${ }^{200}$ We wrześniu tegoż roku sporządzono futerał mosiężny na piszczałki dla jednego z fajfrów za 8 zł. Nie wiemy, kiedy i w jaki sposób doszło do zakupu brakującego sprzętu muzycznego. Najprawdopodobniej braki te uzupełniono w 1754 r., gdyż w późniejszych rachunkach odnajdujemy jedynie wzmianki dotyczące kosztów wymiany sznurów do bębnów, buntów do ich ściągania, zakupu pałeczek dla doboszów oraz skórek do naciągania na obręczach. Rachunki te powtarzają się z dużą regularnością. ${ }^{201}$ Jeden z bębnów malowany i naprawiany był w $1763 \mathrm{r}^{202}$ Dopiero w $1768 \mathrm{r}$. wymieniono obie piszczałki oraz jeden $\mathrm{z}$ bębnów, a drugi poddano renowacji. Piszczałki

\footnotetext{
195 Ibid., Podh IV/XL, plik 12, Specyfikacya szabel..., 1 II - 2 IV 1756 r., b.p.

196 Ibid., Podh IV/XLVII, plik 25, Specyfykacya małego moderunku..., 13 VII 1761 r., b.p.

197 Ibid., plik 44, Regestr percepty y expensy..., 27 VII 1764 r., b.p.; plik 59, Regestr percepty y expensy..., 13 XII 1766 r., b.p.; plik 85, Expens na mundur wielki..., 22 XI 1768 r., b.p.

198 Ibid., Podh IV/L, plik 46, Specyfikacya decessu w mondurze..., 30 XI 1760 r., b.p.; Podh IV/XLVII, plik 38, Specyfikacya potrzeb należących małego moderunku..., 1 X 1763 r., b.p.; plik 44, Regestr percepty y expensy..., 27 VII 1764 r., b.p.

199 Ibid., Podh IV/XLVII, plik 23, Specyfikacya munderunku chorągwi..., 17 VII 1752 r., b.p.

200 Ibid., plik 22, Regestr sprawienia barw na gemeinów..., 16 III 1753 r., b.p.

201 Ibid., Podh IV/XL, plik 1, Specyfikacja drobnego moderunku..., 29 VII 1755 r., b.p.; plik 20, Specyfikacya potrzeb do monduru wielkiego..., 24 IV 1758 r., b.p.; Podh IV/XLVII, plik 17, Rejestr percept y expens..., 11 IV 1754 r., b.p.; plik 44, Regestr percepty y expensy..., 27 VII 1764 r., b.p.; plik 59, Regestr percepty y expensy..., 13 XII 1766 r., b.p.; Podh IV/L, plik 48, Specyfykacya potrzeb należących do monduru wielkiego..., 12 IV 1760 r., b.p.

202 Ibid., Podh IV/XLVII, plik 38, Specyfikacya potrzeb należących małego moderunku..., 1 X 1763 r., b.p.
} 
zakupiono w Warszawie, a bębny naprawiał złotnik w Brodach. Koszt sprawienia instrumentów wyniósł 132 zł i 3 gr. ${ }^{203}$

Futerały na piszczałki wykonane były z mosiądzu i, jak wskazuje na to opis źródłowy, na obu winien znajdować się herb Krzywda. ${ }^{204} \mathrm{Z}$ kolei na bębnie mosiężnym wykonany miał „być w armaturze herb jaśnie wielmożnego pana wojewody, hetmana polnego koronnego" Wacława Rzewuskiego. ${ }^{205}$

Mundur Chorągwi Piechoty Węgierskiej Buławy Polnej Koronnej był wizualnie zdecydowanie bogatszy od „zachodnich” mundurów piechoty koronnej. Na stan ten składały się elementy zaczerpnięte $\mathrm{z}$ węgierskiej tradycji, m.in. żupany nawiązujące do dolmanów, cynowe guzy obszywane dziesiątkami łokci sznurka wełnianego i centkami czy choćby pasy włóczkowe z węzłami, tak charakterystycznymi dla formacji huzarskich. Inne bardzo funkcjonalne rozwiązania, tj. długie do kostek spodnie czy wiązane buty z wysokimi cholewami stały się później wzorem dla piechoty polskiej czasów stanisławowskich. Jednocześnie dzięki tym elementom mundur chorągwi zachował swój węgierski charakter, a żołnierzy upodabniał do pieszych huzarów. Sytuację taką obserwujemy także w armii austriackiej z tego okresu, gdzie regimenty węgierskie zachowują m.in. długie spodnie, sznurowane buty, dołmany w miejsce kamizelek, a także szable typu węgierskiego. ${ }^{206}$

Koszty wykonania poszczególnych elementów umundurowania uzależnione były od dostępności materiałów oraz wahan siły nabywczej pieniądza (zwłaszcza w 1761 r.). W związku z tym obliczenie wartości umundurowania dla żołnierza chorągwi węgierskiej nastręcza pewnych trudności. W przypadku piechoty koronnej było podobnie, jednak w tym przypadku dysponujemy założeniami regulaminowymi pozwalającymi oszacować dokładnie wydatki mundurowe. Na podstawie sporządzonego dla celów roboczych zestawienia można zauważyć jednak, że mundur szeregowego piechoty węgierskiej mieścił się w tych samych widełkach cenowych co mundur szeregowego regimentu pieszego koronnego ${ }^{207}$ Wynikało to $\mathrm{m}$.in. z rezygnacji z niektórych elementów umundurowania, np. kamaszy, guzików i podwiązek do nich, lub zastąpienia kosztowniejszych elementów, jak np. kapelusze trójrożne z kordonem i kokardami, tańszymi kapuzami sukiennymi.

\footnotetext{
203 Ibid., plik 85, Expens na mundur wielki..., 22 XI 1768 r., b.p.

204 Ibid., plik 17, Rejestr percept y expens..., 11 IV 1754 r., b.p.

205 Ibid., plik 13, Specyfikacja rekwizytów..., 29 III 1754 r., b.p.

206 ÖStA/KA, BS L IV, 32, „Allgemeiner Aufriss..., Zwölfter Theil, b.m., [ca. 1769-1773], rkps.

207 AN w Krakowie, AS, Ap, Podh II 263, Obiaśnienie..., [1760 r.], § 7, b.p.
} 


\section{Aneks nr 1}

\begin{tabular}{|c|c|c|}
\hline \multicolumn{3}{|c|}{ Oficerowie } \\
\hline \multirow[t]{2}{*}{ Rotmistrzowie } & Franciszek Bałła & luty $1752 \mathrm{r}^{\mathrm{a}}-7$ września $1768 \mathrm{r} . \dagger$ \\
\hline & Jan Sidorowski & październik? 1768 r. - 1774 r.? \\
\hline \multirow[t]{3}{*}{ Porucznicy } & Michał Erdelli & $\begin{array}{l}\text { (co najmniej od listopada } 1750 \text { r.) - } 13 \text { lutego } \\
1758 \text { r. }\left(\text { apszejt }{ }^{\text {b }}\right)\end{array}$ \\
\hline & Tomasz Watlewskic $^{\mathrm{c}}$ & 13 lutego 1756 r. - 1 września 1765 r. ${ }^{\mathrm{d}}$ (apszejt) \\
\hline & Jan Sidorowski & 3 września 1765 r. - listopad? 1768 r. \\
\hline \multirow[t]{5}{*}{ Chorążowie } & Franciszek Bałła & (co najmniej od września 1750) - luty 1752 r. \\
\hline & Aleksander von Meclem & marzec 1752 r.? - przed lutym $1756 \mathrm{r}^{\mathrm{e}}{ }^{\dagger} \dagger$ \\
\hline & Tomasz Watlewski & 28 lutego 1756 r. - 13 lutego 1758 r. \\
\hline & Adam Horvat & 14 lutego 1758 r. - ok. 20 czerwca 1765 r. $\dagger$ \\
\hline & Wojciech Srzedziński & 20 czerwca 1765 r. - ? \\
\hline \multicolumn{3}{|c|}{ Podoficerowie $^{f}$} \\
\hline \multirow[t]{3}{*}{ Wachmistrzowie } & Adam Horwat & przed wrześniem 1752 r. - 13 lutego 1758 r. \\
\hline & Wojciech Walęcki & marzec 1758 r. - wrzesień 1768 r. \\
\hline & \begin{tabular}{|l|} 
Franciszek Szymański \\
\end{tabular} & $\begin{array}{l}\text { październik } 1768 \text { r. - co najmniej do marca } \\
1769 \text { r. }\end{array}$ \\
\hline \multirow[t]{4}{*}{ Podchorążowie } & Wojciech Walęcki & przed wrześniem 1752 r. - luty 1758 r. \\
\hline & Jakub Rezkowski & marzec 1758 r. - wrzesień $1758 \mathrm{r}$. \\
\hline & Wojciech Srzedziński & październik 1758 r. - 20 czerwca 1765 r. \\
\hline & Władysław Tarnawski & luty 1766 r. - co najmniej do marca 1769 r. \\
\hline \multirow[t]{8}{*}{ Kaprale } & Grzegorz Chomicki & $\begin{array}{l}\text { przed wrześniem } 1752 \text { r. - co najmniej do } \\
\text { marca } 1769 \text { r. }\end{array}$ \\
\hline & Marcin Kopczyński & przed wrześniem 1752 r. - sierpień 1767 r. \\
\hline & Michał Zabiło & $\begin{array}{l}\text { październik } 1767 \text { r. - co najmniej do marca } \\
1769 \text { r. }\end{array}$ \\
\hline & Jan Czajkowski & przed wrześniem 1752 r. - listopad 1756 r. \\
\hline & Jakub Rezkowski & grudzień 1756 r. - luty 1758 r. \\
\hline & Jan Wesołowski & marzec 1758 r. - wrzesień 1762 r. \\
\hline & Jan Stefankiewicz & październik 1762 r. - sierpień 1768 r. \\
\hline & Maciej Krolaszyńskig & $\begin{array}{l}\text { wrzesień } 1768 \text { r. - co najmniej do marca } \\
1769 \text { r. }\end{array}$ \\
\hline \multirow[t]{2}{*}{ Felczerzy } & Jędrzej Morakowski & przed wrześniem 1752 r. - kwiecień 1762 r. \\
\hline & Wolf Jankielowicz & $\begin{array}{l}\text { październik } 1762 \text { r. - co najmniej do marca } \\
1769 \text { r. }\end{array}$ \\
\hline
\end{tabular}

a Awansował na rotmistrza $\mathrm{z}$ chorążego w miejsce pułkownika L. Małachowskiego; AN w Krakowie, AS, Ap, Podh II 74, Rolla piechoty węgierskiej jo. kasztelana krakowskiego, hetmana wielkiego koronnego, b.m., [maj 1751 r.], b.p. 
b Apszejt, abszeyt - dymisja, zwolnienie (z niem. Abschied - pożegnanie); w XVIII w., dokument poświadczający zwolnienie ze służby wojskowej.

c Do gaży oficerskiej przysługiwał Watlewskiemu specjalny dodatek 400 zł rocznie za grę „co dzień po obiedzie na lutni przez pół godziny”; AN w Krakowie, AS, Ap, Podh IV/XL, plik 10, [Oświadczenie Tomasza Watlewskiego], Podhorce, 28 II 1756 r., b.p.

d Po otrzymanym apszejcie dostał 1 II 1766 r. patent na generał adiutanta; ibid., Podh II 111, Patent na generał adiutaństwo Tomaszowi Watlewskiemu, Podhorce, 1 II 1766 r., 303.

e Ibid., Podh II 111, Patent na chorąstwo Tomaszowi Watlewskiemu, Podhorce, 28 II 1756 r., 118.

f Na podstawie ibid., Podh III, pudło IV/1, pliki 1-215f, Rolle lenungowe, wrzesień 1752 r. - marzec 1769 r., b.p.

g Wcześniej służył w Leibkompanii Regimentu Pieszego Buławy Polnej Koronnej (od 14 X 1757 r. do co najmniej sierpnia 1767 r., w tym jako kapral od 21 VI 1764 r.), od września 1767 r. w chorągwi piechoty węgierskiej.

Aneks nr 2

Lista muzyków Chorągwi Piechoty Węgierskiej Buławy Polnej Koronnej w okresie wrzesień 1752 - marzec 1769 r.

\section{Fajfrzy}

1. Buczko Piotr: fajfer (listopad 1754 r. - wrzesień 1760 r.), gemeine (październik 1760 r. co najmniej do marca 1769 r.).

2. Dzwoniecki Ignacy, gemeine (luty-wrzesień 1760 r.), fajfer (październik 1760 - marzec 1769, co najmniej od 1775 r.) jako gemeine, w okresie listopad 1782 r. - luty 1783 r. kapral, apszejtowany przed wrześniem 1783 r., w kwietniu 1762 r. również jako dobosz.

3. Kopczyński Marcin, kapral (od września 1752 r. do sierpnia 1767 r.), fajfer (marzec $1768 \mathrm{r}$.).

4. Lewandowski Mikołaj, gemeine (luty-wrzesień 1760 r.), fajfer (październik 1760 r. - czerwiec 1764 r.).

5. Wasilewski Marcin, fajfer (lipiec 1764 r. - luty 1768 r., kwiecień 1768 r. co najmniej do marca 1769 r.).

6. Wierzbicki Sebastian, ur. 1735, w chorągwi od 1743 r., fajfer (przed wrześniem 1752 r. - wrzesień 1760 r.), gemeine (październik 1760 r. 17 luty 1775 r.), katolik, pochodził z Podola.

\section{Dobosze}

1. Balicki Maciej, gemeine (czerwiec 1763 r.), dobosz (lipiec 1763 r. co najmniej do marca 1769 r.), gemeine w 1775 r., miał żonę i dzieci.

2. Bisiur Wojciech, dobosz (październik 1759 r. - maj 1760 r., lipiec 1760 r. - czerwiec 1763 r.), gemeine (lipiec 1763 r. - co najmniej do lutego 1775 r.). 
3. Dzwoniecki Ignacy, kwiecień 1762 r. jednocześnie jako dobosz i fajfer, zob. fajfrzy.

4. Jankowski Franciszek, dobosz (grudzień 1758 r.).

5. Kopczyński Jan, dobosz (od września 1752 r. - 7 lipca 1759 r.), gemeine (8 lipiec 1759 r. - maja 1760 r.), dobosz, czerwiec 1760 r., gemeine (lipiec 1760 r. - grudzień 1764 r.).

6. Lendgoszewski Jan, dobosz (styczeń 1757 r. - listopad 1758 r.).

7. Majewski Józef, gemeine (listopad 1754 r. - październik 1758 r.), następnie zawerbowany jako dobosz (październik 1761 r. - marzec 1762 r.; maj 1762 r. - marzec 1765 r.).

8. Meron Jan, gemeine (lipiec-wrzesień 1760 r.), dobosz (październik 1760 r. - grudzień 1760 r.; kwiecień-sierpień 1765 r.).

9. Mielaszyński Mikołaj, dobosz (wrzesień 1765 r. - co najmniej do marca 1769 r.).

10. Mosakiel Stanisław, dobosz (kwiecień 1759 r. - wrzesień 1760 r.), gemeine (październik - grudzień 1760 r.), dobosz (styczeń-kwiecień 1761 r.).

11. Niedzielski Józef, dobosz (lipiec-wrzesień 1759 r.).

12. Wierzbicki Antoni, dobosz (od września 1752 r. - grudzień 1756 r.), gemeine (styczeń 1757 r. - sierpień 1768 r.), w okresie luty-marzec 1759 r. oraz lipiec-sierpień $1761 \mathrm{r}$. jako dobosz.

\section{Bibliografia}

\section{Archiwalia}

Archiwum Narodowe w Krakowie

Archiwum Sanguszków, Archiwum Podhoreckie

Osterreichischen Staatsarchiv-Kriegsarchiv w Wiedniu

Bildersammlung und audiovisuelle Sammlungen

\section{Rękopisy i źródła drukowane}

Bystrzonowski, Wojciech. Informacya matematyczna rozumnie ciekawego Polaka. Lublin: Societatis JESU, 1743.

Raspe, Garbiel Nicolaus. Accurate Vorstellung der Königlich Pohlnischen Armee nach der auf dem in Jahre 1775 gehaltenen Reichstage festgesetzten Stärke und Uniform. Nürnberg: Raspe, Gabriel Nikolaus, 1781.

\section{Opracowania}

Arct, Michał. Słownik staropolski. Warszawa: Wydawnictwo M. Arcta, ca 1920.

Bleckwenn, Hans. Die Ökonomie-Reglements des Altpreussische Heeres. Osnabrück: Biblio Verlag, 1973.

Ciesielski, Tomasz. Armia koronna w czasach Augusta III. Warszawa: Wydawnictwo DiG, 2009. 
Gembarzewski, Bronisław. Rodowody pułków i oddziałów równorzędnych od r. 1717 do r. 1831. Warszawa: Towarzystwo Wiedzy Wojskowej, 1925.

Gembarzewski, Bronisław. Żołnierz polski. Ubiór, uzbrojenie i oporządzenie od wieku XI do roku 1960., T. 2. Od 1697 do 1794. Warszawa: Wyd. Ministerstwa Obrony Narodowej, 1962.

Górski, Konstanty. Historya piechoty polskiej. Kraków: Księgarnia Spółki Wydawniczej Polskiej, 1893.

Heigelin, Johann Friedrich. Allgemeines Fremdwörter-Handbuch für Teutsche. Tübingen: Verlag von E. F. Osiander, 1838.

Hohrath, Daniel. The Uniforms of the Prussian Army under Frederick the Great from 1740 to 1786. Vienna: Verlag Militaria, 2011.

Karłowicz, Jan, Adam Kryński i Władysław Niedźwiedzki, Władysław. Red. Słownik języka polskiego. T. 2. H-M. Warszawa: Kasa im. Mianowskiego, 1902.

Karpiński, Tomasz. „Rola Leszna w zaopatrzeniu piechoty koronnej w umundurowanie i ekwipunek za czasów Augusta III - wybór źródeł." Rocznik Leszczyński 19 (2019): 225-269.

Kling, Constantin. Allgemeine Geschichte der Bekleidung und Ausrüstung des altpreussischen Heeres, Dritte theil: Die Kürrasier und Dragoner-Regimenter seit anfangs des 18 Jahrhunderts bis 1808. Weimar: Buch und Steindruckerei von Putze \& Hölzer, 1906.

Machynia, Mariusz i Srzednicki Czesław. Oficerowie wojska Koronnego 1777-1794: spisy. Cz. 1. Sztaby i kawaleria. Kraków: Księgarnia Akademicka, 2002.

Ostrowski, Jan K., Oksana Kozyr, Jerzy T. Petrus, Tatiana Sabodasz i Angela Sołtys. Podhorce: dzieje wnętrz pałacowych i galerii obrazów. Kraków: Zamek Królewski na Wawelu, 2001.

Schedel, Johann Christian. Neues und vollständiges, allgemeines Waaren-Lexikon. Band 2. Offenbach am Mayn: Carl Ludwig Brede, 1814.

\section{Prasa}

Amtsblatt zur Lemberger Zeitung. Dziennik urzędowy do Gazety Lwowskiej, nr 251, listopad 4, 1853.

\section{Prace niepublikowane}

Hottó, Eva. „Dekonstrukció és rekonstrukcióa XVII-XVIII. Századi magyar férfi öltözetek jellemző szabásformáinak rekonstrukciós elemzése." Maszynopis pracy doktorskiej. Nyugat-Magyarországi Egyetem, Sopron, 2014, mps.

\section{Internet}

Szabó, Csabáné. „Egy 18. századi férfi öltözet restaurálása” www.egrivar.hu. Dostęp kwiecień 6, 2021. http://www.egrivar.hu/dobo-istvan-varmuzeum/szakmai-mun ka/blog/421-18-szazadi-ferfi-oltozet-restauralasa?fbclid=IwAR0t4ojZ2SNAaSBP eH-it5iNvVbidgNQ3hFcOWee2kA8volqmyycQSjedzU.

\section{Obrazy}

Portret Franciszka Bałły, Muzeum Narodowe w Warszawie, sygn. MP 2445 MNW; 5622 Tc 75. 


\section{STRESZCZENIE}

\section{Tomasz Karpiński, Umundurowanie Chorągwi Piechoty Węgierskiej Buławy Polnej Koronnej w latach 1752-1768}

Po śmierci dotychczasowego hetmana wielkiego Józefa Potockiego jego chorągiew piechoty węgierskiej została zdegradowana do rangi chorągwi buławy polnej. W czerwcu 1752 r. oddział udał się do Podhorzec, gdzie miał pełnić rolę oddziału przybocznego przy hetmanie polnym koronnym Wacławie Rzewuskim. Oddział prócz pełnienia służby garnizonowej stanowił asystę hetmańską w rozlicznych podróżach. Chorągiew Piechoty Węgierskiej Buławy Polnej Koronnej w latach 1752-1768 liczyła 6 podoficerów, 2 fajfrów, 2 doboszy i 60 szeregowych. Mundur żołnierzy przyjął barwy noszone przez inne oddziały buławy polnej tj. czerwono-szafirowe. Piechota węgierska zachowała swój tradycyjny madziarski charakter stroju, jednak sposób jego zakupu i wydawanie nawiązywał do rozwiązań stosowanych w piechocie autoramentu cudzoziemskiego. Autor w niniejszym opracowaniu przedstawił ustalenia dotyczące umundurowania obowiązującego w chorągwi, sposobów jego pozyskiwania i utrzymania, w tym napraw w czasie służby. Przedstawił również elementy wyposażenia żołnierzy oraz ich uzbrojenia.

Słowa kluczowe: armia koronna, „Węgrzy”, piechota węgierska, umundurowanie, piechota, mundur

\section{SUMMARY}

\section{Tomasz Karpiński, The Uniform of the Hungarian Crown Field Mace Infantry Banner between 1752-1768}

After the death of the former Grand Hetman Józef Potocki, his Hungarian infantry banner was downgraded to the rank of a field mace banner. In June 1752, the detachment went to Podhorzec, where it was to act as a bodyguard for the Field Crown Hetman Wacław Rzewuski. The unit, apart from performing garrison duties, accompanied the Hetman on numerous journeys. Between 1752-1768 the unit consisted of 6 non-commissioned officers, 2 pipers, 2 drummers and 60 privates. The uniform worn by the soldiers adopted the colors worn by other units of field mace, i.e. red-sapphire, and it retained its traditional Hungarian character, however the way it was purchased and issued was related to solutions adopted by foreign infantry units. In this study, the author presents the arrangements for the uniforms used by the infantry unit, the methods used to obtain it, and how it was maintained and repaired during service. Certain elements of soldierly equipment and the weapons they used are also discussed.

Keywords: crown army, „Hungarians”, Hungarian infantry, military uniforms, infantry, uniform 


\section{АННОТАЦИЯ}

\section{Томаш Карпиньски, Военная форма Хоругви венгерской пехоты} Полевой Коронной Булавы в 1752-1768 гг.

После смерти великого гетмана Юзефа Потоцкого его хоругвь венгерской пехоты была понижена до ранга хоругви полевой булавы. В июне 1752 г. отряд отправился в Подгорцев, где он должен был действовать в качестве охранного отряда у коронного полевого гетмана Вацлава Ржевуского. Отряд, помимо несения гарнизонной службы, выполнял ассистентскую функцию для гетмана в многочисленных поездках. В 1752-1768 гг. Хоругвь венгерской пехоты Полевой Коронной Булавы состояла из 6 унтер-офицеров, 2 дудочников, 2 барабанщиков и 60 рядовых. Военная форма солдат поменяла свои цвета на те, которые носили другие отряды полевой булавы, то есть красносапфировые. Венгерская пехота сохранила свой традиционный венгерский характер экипировки, но способ ее приобретения и выдачи был связан с решениями, используемыми в иностранной пехоте. В данном исследовании автор представил данные, касающиеся военной формы в хоругви, способы ее приобретения и сохранения, включая ремонт, во время службы. Он также представил элементы экипировки солдат и их вооружение.

Ключевые слова: коронная армия, „Венгры”, венгерская пехота, обмундирование, пехота, военная форма 